University of Nebraska - Lincoln

DigitalCommons@University of Nebraska - Lincoln

Biological Systems Engineering: Papers and

Publications

Biological Systems Engineering

2016

\title{
Quantifying the fate of agricultural nitrogen in an unconfined aquifer: Stream-based observations at three measurement scales
}

\author{
Troy E. Gilmore \\ University of Nebraska-Lincoln, gilmore@unl.edu \\ David P. Genereux \\ North Carolina State University, genereux@ncsu.edu \\ D. Kip Solomon \\ University of Utah, kip.solomon@utah.edu \\ John E. Solder \\ Utah Water Science Center \\ Briant A. Kimball \\ Utah Water Science Center
}

See next page for additional authors

Follow this and additional works at: https://digitalcommons.unl.edu/biosysengfacpub

Part of the Bioresource and Agricultural Engineering Commons, Environmental Engineering Commons, and the Other Civil and Environmental Engineering Commons

Gilmore, Troy E.; Genereux, David P.; Solomon, D. Kip; Solder, John E.; Kimball, Briant A.; Mitasova, Helena; and Birgand, Francois, "Quantifying the fate of agricultural nitrogen in an unconfined aquifer: Streambased observations at three measurement scales" (2016). Biological Systems Engineering: Papers and Publications. 472.

https://digitalcommons.unl.edu/biosysengfacpub/472

This Article is brought to you for free and open access by the Biological Systems Engineering at DigitalCommons@University of Nebraska - Lincoln. It has been accepted for inclusion in Biological Systems Engineering: Papers and Publications by an authorized administrator of DigitalCommons@University of Nebraska Lincoln. 


\section{Authors}

Troy E. Gilmore, David P. Genereux, D. Kip Solomon, John E. Solder, Briant A. Kimball, Helena Mitasova, and Francois Birgand 


\section{Water Resources Research}

\section{RESEARCH ARTICLE \\ 10.1002/2015WR017599 \\ Key Points: \\ Quantifying the fate of agricultural nitrogen in an unconfined aquifer: Stream-based observations at three measurement scales}

- Point, seepage meter, and reachscale methods quantified aquifer $\mathrm{NO}_{3}$ discharge

- Results depended on the degree of channel influence on the sampling method

- Streambed point results were related to patterns of watershed land and $\mathrm{N}$ use

Supporting Information: - Supporting Information S1 - Table S1

Correspondence to:

T. E. Gilmore,

gilmore@unl.edu

Citation:

Gilmore, T. E., D. P. Genereux,

D. K. Solomon, J. E. Solder,

B. A. Kimball, H. Mitasova, and

F. Birgand (2016), Quantifying the fate

of agricultural nitrogen in an unconfined aquifer: Stream-based observations at three measurement scales, Water Resour. Res., 52, 19611983, doi:10.1002/2015WR017599.

Received 22 MAY 2015 Accepted 12 DEC 2015 Accepted article online 2 FEB 2016 Published online 16 MAR 2016

\author{
Troy E. Gilmore1,2,3, David P. Genereux², D. Kip Solomon4, John E. Solder4,5, Briant A. Kimball6, \\ Helena Mitasova², and François Birgand ${ }^{1}$
}

\begin{abstract}
${ }^{1}$ Department of Biological and Agricultural Engineering, North Carolina State University, Raleigh, North Carolina, USA, ${ }^{2}$ Department of Marine, Earth, and Atmospheric Sciences, North Carolina State University, Raleigh, North Carolina, USA, ${ }^{3}$ Now at Conservation and Survey Division and Department of Biological Systems Engineering, University of Nebraska, Lincoln, Nebraska, USA, ${ }^{4}$ Department of Geology and Geophysics, University of Utah, Salt Lake City, Utah, USA, ${ }^{5}$ Now at United States Geological Survey, Utah Water Science Center, Salt Lake City, Utah, USA, ${ }^{6}$ United States Geological Survey, Utah Water Science Center, Salt Lake City, Utah, USA
\end{abstract}

\begin{abstract}
We compared three stream-based sampling methods to study the fate of nitrate in groundwater in a coastal plain watershed: point measurements beneath the streambed, seepage blankets (novel seepage-meter design), and reach mass-balance. The methods gave similar mean groundwater seepage rates into the stream $(0.3-0.6 \mathrm{~m} / \mathrm{d}$ ) during two 3-4 day field campaigns despite an order of magnitude difference in stream discharge between the campaigns. At low flow, estimates of flowweighted mean nitrate concentrations in groundwater discharge $\left(\left[\mathrm{NO}_{3}^{-}\right]_{\mathrm{FWM}}\right)$ and nitrate flux from groundwater to the stream decreased with increasing degree of channel influence and measurement scale, i.e., $\left[\mathrm{NO}_{3}^{-}\right]_{\mathrm{FWM}}$ was 654,561 , and $451 \mu \mathrm{M}$ for point, blanket, and reach mass-balance sampling, respectively. At high flow the trend was reversed, likely because reach mass-balance captured inputs from shallow transient high-nitrate flow paths while point and blanket measurements did not. Point sampling may be better suited to estimating aquifer discharge of nitrate, while reach mass-balance reflects full nitrate inputs into the channel (which at high flow may be more than aquifer discharge due to transient flow paths, and at low flow may be less than aquifer discharge due to channel-based nitrate removal). Modeling dissolved $\mathrm{N}_{2}$ from streambed samples suggested (1) about half of groundwater nitrate was denitrified prior to discharge from the aquifer, and (2) both extent of denitrification and initial nitrate concentration in groundwater $(700-1300 \mu \mathrm{M})$ were related to land use, suggesting these forms of streambed sampling for groundwater can reveal watershed spatial relations relevant to nitrate contamination and fate in the aquifer.
\end{abstract}

\section{Introduction}

Direct measurement of nitrogen $(\mathrm{N})$ fluxes from groundwater to streams is needed to assess the contribution of contaminated groundwater to water quality impairment in streams and estuaries, and associated algal blooms, hypoxia, and fish kills [Diaz and Rosenberg, 1995; Hayashi and Rosenberry, 2002; Paerl et al., 2006; Obenour et al., 2012]. Groundwater discharge to streams can account for a large fraction of total stream flow [Bachman et al., 1998; Winter et al., 1998; Alley et al., 1999; Holmes, 2000; Clow et al., 2003; Lindsey et al., 2003; Puckett et al., 2008]. In this paper, we address the challenge of using field measurements to quantify the two principal fates of nitrate in an unconfined aquifer: discharge from the aquifer to a stream, and denitrification in the aquifer. Solomon et al. [2015], Gilmore [2015], and Gilmore et al. [2016] explore the mean and distribution of groundwater transit times, and their relationship to nitrate flux and fate, in the same aquifer.

Most of our measurements were conducted in the streambed of an agricultural watershed, an informationrich zone where groundwater $\mathrm{N}$ signals from decades of agricultural land use may be sampled as groundwater discharges to the stream [Lindsey et al., 2003; Böhlke et al., 2004, 2007; Duff et al., 2008; Tesoriero, 2005; Tesoriero et al., 2013; Kennedy et al., 2009a, 2009b; Stelzer et al., 2011a, 2011b]. Kalbus et al. [2006] reviewed the limited number of approaches available for observing groundwater-surface water exchange but did not 


\begin{tabular}{|c|c|c|c|}
\hline \multirow[b]{2}{*}{ Issue or characteristic } & \multicolumn{3}{|c|}{ Approach } \\
\hline & Point & Blanket & $\mathrm{RMB}$ \\
\hline Shows patterns of concentrations and fluxes on streambed & Yes & Somewhat & No \\
\hline Integration by calculation or by nature & Calculation & Both & Nature \\
\hline Samples individual groundwater flowlines & Possibly & No & No \\
\hline Number of samples, cost of analysis & High & Moderate & Low \\
\hline Samples solely groundwater (no mixing with stream) & Yes & Somewhat & No \\
\hline Detection of seepage discharge above the water line & No & No & Yes \\
\hline gw input $\ll$ stream discharge causes high uncertainty & No & No & Yes \\
\hline Feasible in all streambed types & No & No & Yes \\
\hline Requires injected tracers in stream & No & Likely & Yes \\
\hline
\end{tabular}

make quantitative comparisons. We simultaneously applied three approaches, each with a different measurement support scale and balance of pros and cons:

1. the streambed point approach, based on point-scale measurements of both streambed seepage rate and the concentrations of solutes ( $\mathrm{N}$ species, dissolved gases) in groundwater in or just below the streambed [Kennedy et al., 2009a,b],

2. the streambed blanket approach, based on collection of groundwater seepage beneath an experimental "seepage blanket" deployed on top of the streambed [Solder, 2014], and

3. the reach mass-balance approach, based on estimating, from tracers released to the stream, the groundwater input to a stream reach and N concentrations in that input [McMahon and Böhlke, 1996; Stolp et al., 2010].

In this work, the streambed point approach was based on numerous point measurements within or just below the streambed, each with an effective scale on the order of $\sim 0.1 \mathrm{~m}^{2}$ or less in terms of streambed area. Streambed blanket sampling integrated groundwater seepage over streambed areas of just under $1 \mathrm{~m}^{2}$. Reach mass-balance involved the natural integration of groundwater flow paths in a receiving stream reach at reach length scales of $10^{2}-10^{3} \mathrm{~m}$, or streambed area scales of $10^{2}-10^{4} \mathrm{~m}^{2}$ for a stream width of $1-10 \mathrm{~m}$.

During our two 3-4 day field campaigns, stream and groundwater samples collected at the point, seepage blanket, and reach mass-balance scales were analyzed for dissolved $\mathrm{N}$ species $\left(\mathrm{N}_{2}, \mathrm{NO}_{3}^{-}, \mathrm{NH}_{4}^{+}\right)$, noble gases $(\mathrm{Xe}, \mathrm{Kr}, \mathrm{Ne}, \mathrm{Ar}, \mathrm{He})$, and other geochemical parameters. These data were combined with groundwater discharge estimates at each of the three spatial scales. The overall purpose was to compare the three field sampling scales to see if they give fundamentally different pictures of the fate of agricultural nitrate in the surficial aquifer, specifically (1) the water and $\mathrm{N}$ flux out of the aquifer to the study stream, and (2) the extent of denitrification in the groundwater discharging into the stream.

\section{Background}

\subsection{Overview of Sampling Approaches}

The different spatial scales of integration inherent in the three approaches (point, blanket, and reach massbalance) suggest contrasting general pros and cons (Table 1).

\subsection{Streambed Point Approach}

Groundwater $\mathrm{N}$ fluxes into streams have previously been measured using the point approach [Kennedy et al., 2007, 2008, 2009a, 2009b]. For closely spaced points, N concentration and groundwater age showed distinct patterns in the streambed, suggesting that point samples were representative of individual (relatively unmixed) groundwater flowlines and making it possible to relate point $\mathrm{N}$ fluxes to controlling factors such as streambed permeability, groundwater age, or extent of denitrification. Other studies have combined groundwater concentrations from point sampling with groundwater inflow estimates from reach massbalance [Böhlke et al., 2004; Duff et al., 2008; Stelzer et al., 2011a] but have largely focused on in-stream cycling of $\mathrm{N}$. Unlike reach mass-balance, point measurements do not require injected tracers and can quantify groundwater discharge even if it is small relative to stream discharge. The point approach requires both 


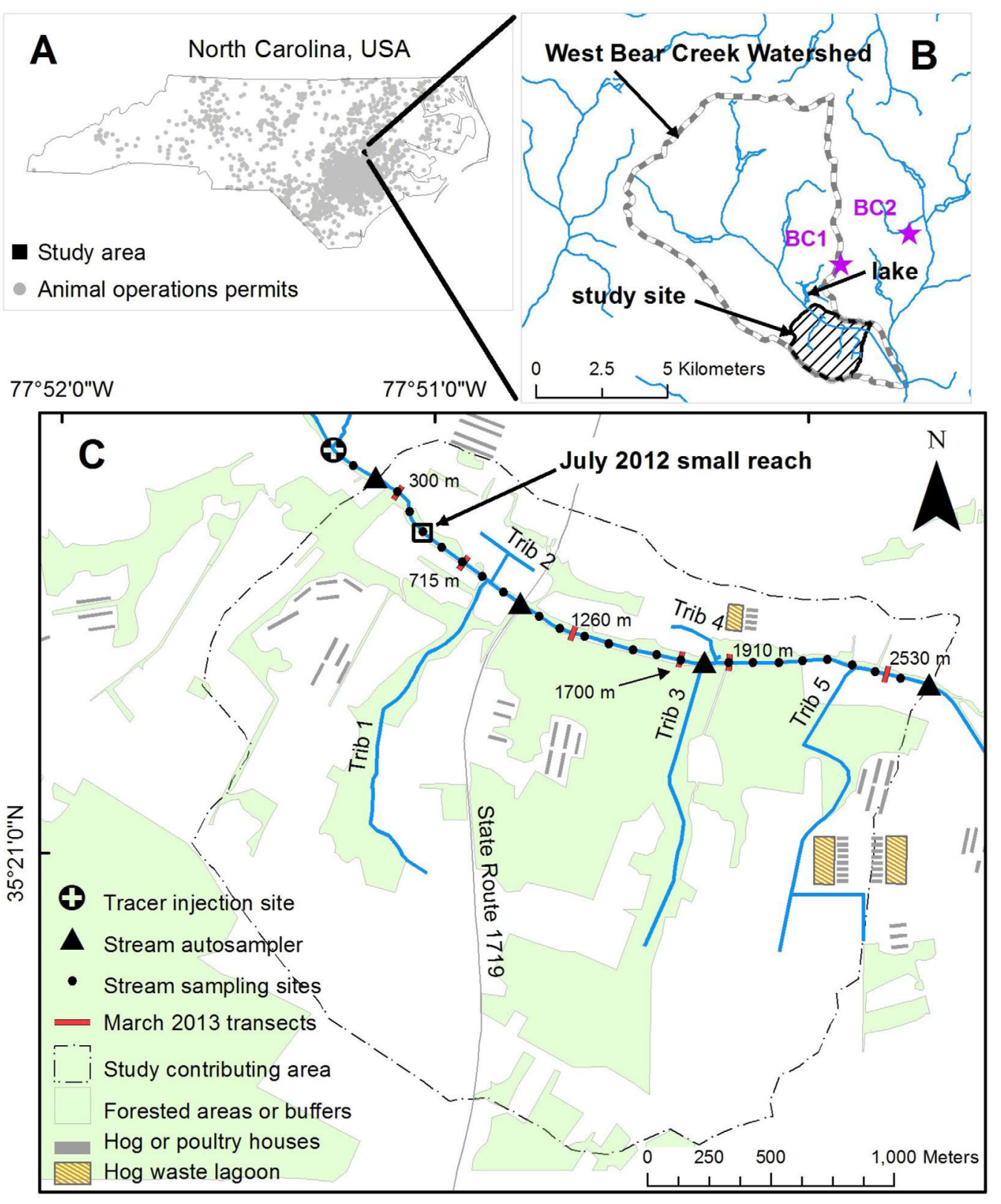

Figure 1. West Bear Creek study site layout for the July 2012 and March 2013 field campaigns. (a) Animal feeding operations in North Carolina. (b) The West Bear Creek watershed is outlined by the thick gray-dashed line, and the topographically defined contributing area for the $2.5 \mathrm{~km}$ study reach is defined by the cross-hatched area. Well nests are denoted by stars. (c) The topographically defined contributing area for the West Bear Creek study reach (outlined by thin dot-dash line), with hog and poultry houses and forested areas shown. Stream autosamplers were $0.2-2.7 \mathrm{~km}$ downstream of the tracer injection site. Stream sampling sites (small black circles) were distributed at $100 \mathrm{~m}$ intervals. In July 2012, all eight point transects and two blanket transects were in the 58 m "July 2012 small reach." Six March 2013 point transects distributed throughout the $2.5 \mathrm{~km}$ reach are labeled by their distances in meters downstream of the injection site. Blanket sampling was also conducted at the $715 \mathrm{~m}$ transect in March. All GIS data were accessed via the NC OneMap Geospatial Portal (data.nconemap.com). Forested areas, agricultural facilities, and tributaries were defined using digital orthophotos (2010 North Carolina Statewide Digital Orthoimagery) and field observations. The contributing area for the $2.5 \mathrm{~km}$ reach is based on digital elevation data from the North Carolina Department of Transportation. The West Bear Creek watershed outline is from the USDA NC NRCS 12-Digit Hydrologic Units data set. The main channel of West Bear Creek and locations for animal operations permits were from data sets of the North Carolina Department of Environmental Quality (NCDEQ), formerly (before 18 September 2015) the NC Department of Environment and Natural Resources (NCDENR).

groundwater sampling and seepage rate measurement at each streambed point to calculate $\mathrm{N}$ flux and flowweighted mean $\mathrm{N}$ concentration in the groundwater, and is applicable in streambeds where groundwater probes can be installed and sampled. Flow-weighting is especially critical: without it, there is no way to know how best to average spatially variable groundwater chemistry to quantify net $\mathrm{N}$ discharge from the aquifer. 

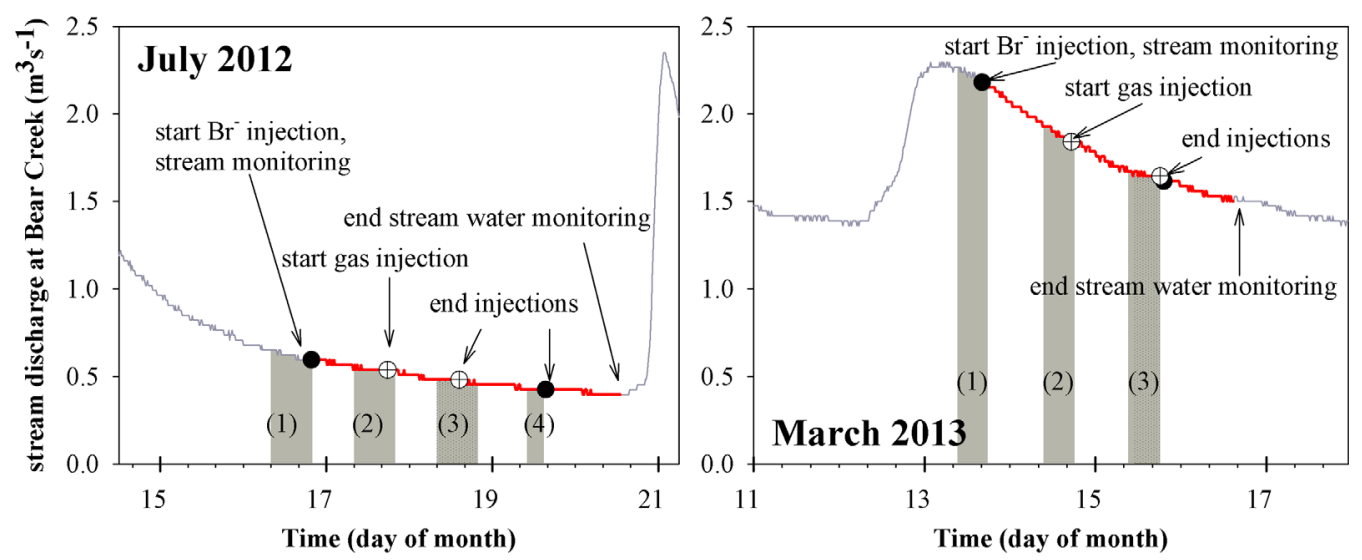

Figure 2. Hydrologic conditions and timelines for the July 2012 and March 2013 field campaigns. Hydrographs are from the USGS stream gage at Mays Store, NC, downstream of the study site. Tick labels on the horizontal axes indicate the start of each date shown, and intermediate ticks are located at $8 \mathrm{~h}$ intervals. Start and end times for the $\mathrm{Br}^{-}$and gas injections are indicated. Numbered gray bars indicate times during which field work occurred: (1) background sampling for $\mathrm{Br}^{-}$and dissolved gases in stream water (pre-injection), and point sampling, (2) point and blanket sampling, (3) sampling for $\mathrm{Br}^{-}$and dissolved gases in stream water (post injection, with exact time period highlighted by stippling on shaded area), manual stream gauging, and (in March) additional point sampling, (4) additional blanket sampling (July).

\subsection{Streambed Seepage Blanket Approach}

Seepage meters offer an intermediate measurement scale between the point and reach mass-balance approaches and have been a common tool for measuring groundwater flux through lakebeds or streambeds [Bouwer and Rice, 1968; Lee, 1977; Rosenberry, 2008; Solder, 2014]. Individual seepage meters typically integrate groundwater signals on the scale of $<1 \mathrm{~m}^{2}$ (the streambed area covered by a meter) [Kalbus et al., 2006], although larger streambed areas can be integrated using "ganged" seepage meters [Rosenberry, 2005]. Groundwater flux estimates from traditional seepage meters have been compared to other measurement methods [Cey et al., 1998; Rosenberry and Pitlick, 2009; Kennedy et al., 2010], with limited agreement. While the seepage meter concept is theoretically simple, the literature addressing seepage meter performance [Corbett et al., 2003; Murdoch and Kelly, 2003], calibration [Rosenberry and Menheer, 2006], and design improvements [Krupa et al., 1998] suggests that obtaining reliable results is not trivial.

\subsection{Reach Mass-Balance Approach}

Relatively few studies have used the reach mass-balance approach for the primary purpose of calculating the discharge of N from a surficial aquifer [McMahon and Böhlke, 1996; Burns, 1998; Chestnut and McDowell, 2000; Angier and McCarty, 2008; Stelzer et al., 2011a], possibly because in-stream processes may be expected to alter the apparent groundwater N flux at the reach scale [Laursen and Seitzinger, 2002, 2005; Böhlke et al., 2004, 2009; Mullholland et al., 2004; Duff et al., 2008; Gu et al., 2008; Baulch et al., 2010]. Reach mass-balance measurements in streams have been used to estimate groundwater concentrations and groundwater discharges of other solutes, such as volatile organic compounds [Kim and Hemond, 1998], metals from mining activities [Kimball et al., 2002], or dissolved gases [Hemond and Duran, 1989; Genereux et al., 1993; Stolp et al., 2010]. The reach mass-balance approach is well suited for reaches in which the groundwater input is a large percentage of stream discharge. Groundwater discharge fluxes are inherently integrated with this approach so no mathematical integration is necessary, but it is only possible to observe the spatial structure of groundwater inputs at a coarse scale. Groundwater N input to a stream reach is computed as the N flux out the downstream end of the reach minus the $\mathrm{N}$ flux in the upstream end of the reach (minus any $\mathrm{N}$ flux from tributaries), possibly with a correction for in-channel N "retention" (referred to from here forward as simply N loss or removal rather than the commonly-used "retention"). Reach mass-balance generally requires fewer samples which lowers analytical costs, but this may be partially offset by the cost of the injected tracers generally used.

\section{Study Area and Hydrologic Conditions}

\subsection{Study Site}

Field campaigns were conducted in West Bear Creek in July 2012 and March 2013. West Bear Creek is about $6.5 \mathrm{~m}$ wide, channelized and entrenched, and located in a productive agricultural area (Figure 1a) in the 
Table 2. Mean Water Quality Parameters for July 2012 and March 2013 Field Campaigns

\begin{tabular}{lcccc} 
Date & Groundwater $^{\mathrm{a}} \mathrm{pH}$ & $\begin{array}{r}\text { Groundwater }{ }^{\mathrm{a}} \text { Conductivity } \\
(\mu \mathrm{S} / \mathrm{cm})\end{array}$ & $\begin{array}{c}\text { Groundwater }{ }^{\mathrm{a}} \text { Temperature } \\
\left({ }^{\circ} \mathrm{C}\right)\end{array}$ & $\begin{array}{r}\text { Stream Water Temperature } \\
\left({ }^{\circ} \mathrm{C}\right)\end{array}$ \\
\hline July 2012 & $4.7(0.5)$ & $224(48)$ & $20.3(1.3)$ & $25.2(1.3)$ \\
March 2013 & $5.1(0.6)$ & $154(87)$ & $13.2(0.9)$ & $12.3(1.8)$ \\
\hline
\end{tabular}

${ }^{a}$ Groundwater values are means from the streambed point measurements. Standard deviations $(1 \sigma)$ are shown in parentheses.

coastal plain of North Carolina. The West Bear Creek watershed (Figure 1b), previously described in Kennedy et al. [2007, 2008, 2009a, 2009b, 2010] and Genereux et al. [2008], has roughly 60\% agricultural land use and is underlain by a sandy surficial aquifer. Geologic cores collected near West Bear Creek suggest aquifer thickness ranging from roughly 10 to $18 \mathrm{~m}$ [Kennedy et al., 2009a, Gilmore et al., 2016]. The study was conducted in the stream reach between a tracer injection site and a monitoring site $2.7 \mathrm{~km}$ downstream (Figure 1c). The furthest-upstream measurements were made $200 \mathrm{~m}$ downstream of the tracer injection site, thus the study reach was effectively $2.5 \mathrm{~km}$ in length (200-2700 m). The topographically defined contributing area of the $2.5 \mathrm{~km}$ reach comprises about $10 \%$ of the West Bear Creek watershed and contains two concentrated animal feeding operations (at the waste lagoons in Figure 1c). Land not forested is primarily used for row crops, with the exception of pasture for cattle along the north side of the stream, roughly between the 1260 and $2530 \mathrm{~m}$ stream sites.

Kennedy et al. [2009a] observed high $\mathrm{NO}_{3}^{-}$concentration, $\left[\mathrm{NO}_{3}^{-}\right.$], in groundwater seepage to West Bear Creek (mean of $438 \mu M$, range from $<7$ to $1785 \mu M$ ) west of the State Route 1719 bridge (Figure 1c). Kennedy et al. [2009b] found that denitrification was an important process in the surficial aquifer, reducing the nitrate flux from the surficial aquifer to a $75 \mathrm{~m}$ reach of West Bear Creek by about half.

\subsection{Hydrologic Conditions During the Data Collection}

For July 2012 and March 2013, stream discharge at the Bear Creek USGS stream gage (Figure 2; http:// waterdata.usgs.gov/usa/nwis/uv?0208925200), $10 \mathrm{~km}$ downstream of the downstream end of our study reach, was near the 25 year medians for July and March, respectively. In July 2012, groundwater level at NCDEQ well O30J4 $12 \mathrm{~km}$ northwest of the study site (the nearest surficial aquifer well with more than 5 years of water level data, http://www.ncwater.org/) was about $3 \mathrm{~cm}$ above the 30 year historic median for July. In March 2013, water level at the same well was about $29 \mathrm{~cm}$ higher than in July 2012, and about $13 \mathrm{~cm}$ lower than the 30 year historic median for March (the 30 year range in water level at this well, both for July and for March, was about $1 \mathrm{~m}$ ). In March 2013, a precipitation event occurred roughly 3 days before reach mass-balance sampling (Figure 2).

Temperature and basic water quality differed somewhat between the two campaigns (Table 2). Mean temperature from stream temperature probes at 0 and $1000 \mathrm{~m}$ was used in dissolved gas modeling for July 2012 (18 July, 6:30-14:00); data at 0 m were used for March 2013 modeling (15 March, 6:45-17:45). Stream water pH was about 6.6 in July 2012 but was not recorded in March 2013.

\section{Methods}

\subsection{Overview}

The study design and methodology integrated a number of published approaches (Table 3).

Table 3. Field Methods and Study Design 
The following principal groundwater variables were estimated from the field campaigns (Table 4) in July 2012 and March 2013:

1. $v=$ groundwater flux (specific discharge) through the streambed and into the stream $(\mathrm{m} / \mathrm{d})$,

2. $\left[\mathrm{NO}_{3}^{-}\right]=$nitrate concentration in groundwater seepage to the stream (measured on individual point or blanket samples) (all concentrations are in $\mu M$ ),

3. $\left[\mathrm{NO}_{3}^{-}\right]_{\mathrm{FWM}}=$ flow-weighted mean (FWM) nitrate concentration in groundwater seepage to the stream,

4. $\left[\mathrm{NO}_{3}^{-}\right]^{0}=$ initial nitrate concentration in the groundwater at the time of recharge $=$ what $\left[\mathrm{NO}_{3}^{-}\right]$would be in the absence of denitrification

5. $\left[\mathrm{NO}_{3}^{-}\right]_{\mathrm{FWM}}^{0}=$ flow weighted mean initial nitrate concentration in groundwater $=$ what $\left[\mathrm{NO}_{3}^{-}\right]_{\mathrm{FWM}}$ would be in the absence of denitrification,

6. $f_{\mathrm{NO}_{3}}=$ nitrate flux through the streambed from groundwater to the stream $\left(\mathrm{mmol} \mathrm{m}^{-2} \mathrm{~d}^{-1}\right)$,

7. $f_{\mathrm{NO}_{3}}{ }^{0}=$ what $f_{\mathrm{NO} 3}$ would be in the absence of denitrification,

8. $\left[\mathrm{N}_{2}\right.$-den] = the concentration of excess $\mathrm{N}_{2}$ created in the groundwater by denitrification in the groundwater system, and

9. $\left[\mathrm{N}_{2}-\text { den }\right]_{\mathrm{FWM}}=$ flow weighted mean $\left[\mathrm{N}_{2}\right.$-den] in groundwater seepage to the stream.

All solute concentrations presented in this paper are groundwater concentrations, unless otherwise noted.

\subsection{Reach Mass-Balance Methods}

Steady $\mathrm{Br}^{-}$tracer injections to the stream at the $0 \mathrm{~m}$ location (Figure 1c) were used to determine groundwater input to West Bear Creek [Kilpatrick and Cobb 1985; Kimball et al., 1999; Kimball and Runkel, 2009]. Gaseous tracers ( $\mathrm{Kr}, \mathrm{Xe})$ were injected to determine gas transfer velocities for West Bear Creek [Bennett and Rathbun, 1972; Kilpatrick et al., 1989; Wanninkhof et al., 1990; Genereux and Hemond, 1992]. The gas exchange information was needed for trace gas modeling described below. An automated sampler was used to collect stream water samples at the $2700 \mathrm{~m}$ stream monitoring site (Figure 1c) for $\mathrm{Br}^{-}$tracer analysis; sampling frequency was 0.5-2 h. In March 2013, automated sampling also occurred at 200, 1000, and $1800 \mathrm{~m}$ (Figure 1c). In July 2012, the 200, 466, and $524 \mathrm{~m}$ sites were sampled manually at intermittent time intervals.

Manual stream water sampling for the $\mathrm{Br}^{-}$tracer (100 m intervals) was carried out during both campaigns when the stream $\mathrm{Br}^{-}$concentrations reached steady state. Stream water samples for dissolved gas analysis $\left(\mathrm{Xe}, \mathrm{Kr}, \mathrm{Ar}, \mathrm{Ne}, \mathrm{He}, \mathrm{N}_{2}\right.$ ) were also collected but from stations spaced farther apart (Table 4). In March 2013, $\mathrm{NO}_{3}^{-}$samples were collected at the same stream sites used for dissolved gas sampling and from the automated samplers, while in July stream water $\left[\mathrm{NO}_{3}^{-}\right]$was measured in the samples collected for $\mathrm{Br}^{-}$analysis. In July 2012, a DH-81 sampler [Edwards and Glysson, 1999] was used to manually integrate stream water samples across the channel width (to minimize any effects of incomplete lateral stream mixing). In March 2013, temporally averaged concentrations of $\mathrm{Br}^{-}$and $\mathrm{NO}_{3}^{-}$(averaged over roughly a $4-5 \mathrm{~h}$ period) from automated samplers were used for reach mass-balance calculations.

Stream discharge at stream sampling sites was calculated from $\mathrm{Br}^{-}$data using a standard expression for chemical dilution stream gauging (stream discharge $=\mathrm{Br}^{-}$injection rate divided by steady state $\mathrm{Br}^{-}$concentration in stream water) [Kimball et al., 1999]. Groundwater flux based on reach mass-balance was then calculated as:

$$
v=\frac{Q_{\text {down }}-Q_{u p}-\sum Q_{\text {trib }}}{w L}
$$

where $v$ is groundwater flux into West Bear Creek $(\mathrm{m} / \mathrm{d}), Q_{\text {down }}$ and $Q_{u p}$ are the stream discharge at the downstream and upstream ends of the reach, respectively, $Q_{\text {trib }}$ is the inflow from any tributary in the reach, $L$ is the length of the reach, and $w$ is the average width of the stream reach. Solute flux from groundwater into a stream reach $\left(\mathrm{mmol} \mathrm{m}{ }^{-2} \mathrm{~d}^{-1}\right.$ ) was calculated for $\mathrm{NO}_{3}^{-}$and $\mathrm{Cl}^{-}$as:

$$
f=\frac{Q_{\text {down }} C_{\text {down }}-Q_{\text {up }} C_{\text {up }}-\sum Q_{\text {trib }} C_{\text {trib }}}{w L}
$$

where $C$ is the stream water concentration of the solute of interest at the location indicated by the subscript. Flow-weighted solute concentration $(\mu M)$ in the groundwater discharging into the reach $\left(C_{F W M}\right)$ was calculated for $\mathrm{NO}_{3}^{-}$and $\mathrm{Cl}^{-}$as:

$$
C_{F W M}=\frac{Q_{\text {down }} C_{\text {down }}-Q_{u p} C_{u p}-\sum Q_{\text {trib }} C_{\text {trib }}}{Q_{\text {down }}-Q_{u p}-\sum Q_{\text {trib }}}
$$




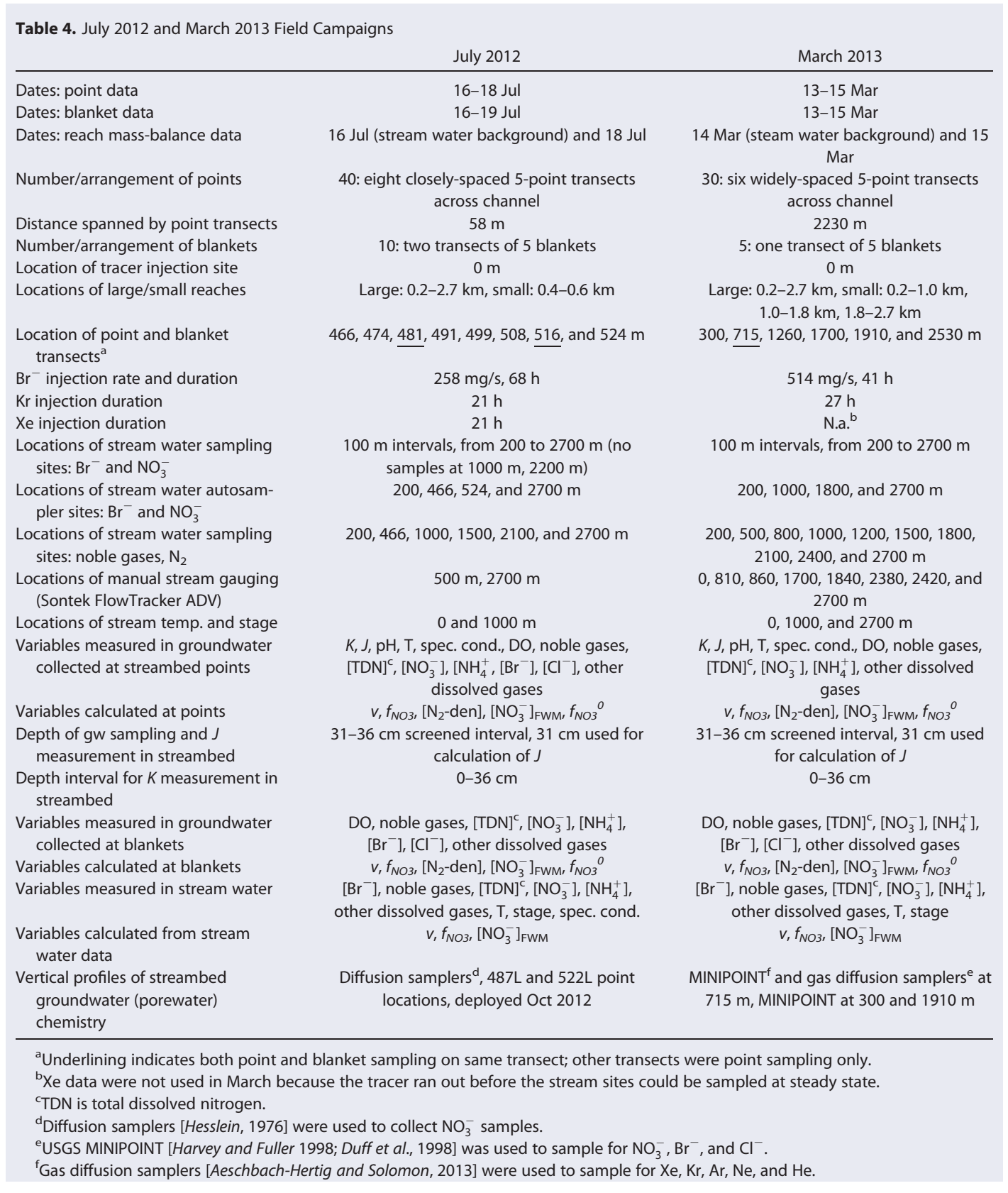

\subsection{Streambed Point Methods}

The point sampling approach involved measuring vertical hydraulic conductivity $(K)$ using an in situ falling head test [Genereux et al., 2008], vertical head gradient $(J)$ using a streambed piezomanometer [Kennedy et al., 2007, 2009b], and streambed groundwater chemistry at streambed points arranged in transects across the channel. This allowed calculation of water flux $(v=K)$ ) and solute flux $(f=v C$, where $C=$ solute concentration) through the streambed at each point. Using uncertainty calculations described in Kennedy et al. [2007] and Genereux et al. [2008], 95\% confidence limits on $K, J$, and $v$ averaged about plus or minus 13\%, $4 \%$, and $14 \%$, respectively (supporting information). In this study, all the measured point fluxes were from groundwater to stream, though fluxes in the opposite direction can also be quantified. The data allowed calculation of $\left[\mathrm{NO}_{3}^{-}\right]_{\mathrm{FWM}}$, where the weighting was by $v$.

The July 2012 campaign used eight 5-point transects spaced roughly $6.5 \mathrm{~m}$ apart between 466 and $524 \mathrm{~m}$ (a 58m reach), while in March 2013 six 5-point transects spanned a distance of over $2.2 \mathrm{~km}$ (Figure 1c, Table 
4). The five sampling locations on each transect were labeled right bank (RB), right (R), center (C), left (L), and left bank (LB) defined with respect to an observer facing downstream (left is the north side of the channel) and were spaced approximately evenly across the stream width (stream width averaged $6.5 \mathrm{~m}$ ). Streambed point sampling in this study differed from that in Kennedy et al. [2009a, 2009b] in two ways: (1) points were added closer to the streambanks to better capture the full range of groundwater discharge, and (2) widely spaced transects (March 2013) were used to capture groundwater input from areas of different land use along the length of the stream.

\subsection{Streambed Seepage Blanket Methods}

Novel streambed seepage meters ("blankets") were used to measure water and $\mathrm{N}$ fluxes. Each rectangular streambed blanket $(71 \mathrm{~cm} \times 107 \mathrm{~cm})$ covered about $0.76 \mathrm{~m}^{2}$ of streambed. Metal flanges attached to the edges of the blankets were inserted about $5 \mathrm{~cm}$ into the streambed. Blankets were made of flexible rubber (Hypalon@) and lined with stainless steel foil to prevent sorption of chlorofluorocarbons (CFCs), age-dating tracers sampled during the study [Gilmore et al., 2016], to the rubber. Each blanket had a central PVC port through which the groundwater captured by the blanket discharged [Solder, 2014]. The blankets were deployed in five blanket transects across the channel, with each transect almost fully covering the streambed from one bank to the other. Blankets had very low profiles above the streambed (about $3 \mathrm{~cm}$ or less, much less than the mean stream depths of about $22 \mathrm{~cm}$ and $27 \mathrm{~cm}$ at the blanket sites in July 2012 and March 2013, respectively), and caused no visible disturbance to stream flow. Blankets were allowed to equilibrate at least $8 \mathrm{~h}$ after installation before discharge measurement or sampling. A dilution flow meter was attached to the PVC port in each blanket and used to determine groundwater discharge from the blanket. Groundwater samples were then collected through a 1/4 inch copper tube inserted into the same port used for the flow meter [Solder, 2014].

In July 2012, blankets were deployed along two transects (481 and $516 \mathrm{~m}$ ), which facilitated direct comparisons ( $n=10)$ with immediately adjacent point measurements at the same transects. In March 2013, only one transect had both blanket and point sampling $(715 \mathrm{~m})$ but the blankets were left in place throughout the entire campaign (3 days), which allowed repeated measurement and more detailed investigation. During the March 2013, campaign time series $\mathrm{Br}^{-}$samples were collected from the blankets and depth profiles of $\mathrm{Br}^{-}$were collected from the sediments at blanket locations using a USGS MINIPOINT sampler (Table 4). In both July and March at least one blanket was not sampled for one or more analytes because of very low flow from the blanket.

Water samples from some blankets contained $\mathrm{Br}^{-}$from the $\mathrm{NaBr}$ stream injection, indicating some mixing of groundwater and surface water beneath those blankets. Given our main objective of estimating fluxes out of the groundwater system (as opposed to total fluxes, groundwater plus surface water, through the top of the streambed), a simple mixing model based on $\left[\mathrm{Br}^{-}\right]$was used to separate groundwater from surface water in these samples and thereby estimate $\left[\mathrm{NO}_{3}^{-}\right]$and $\left[\mathrm{Cl}^{-}\right]$in the groundwater. The fraction of groundwater in blanket outflow $\left(F_{g w}\right)$ was determined as:

$$
F_{g w}=\frac{C_{\text {blanket }}-C_{s w}}{C_{g w}-C_{s w}}
$$

where $C$ is the concentration of $\mathrm{Br}^{-}$, and the subscripts $s w, g w$, and blanket indicate stream water (collected near the location and time of blanket sampling), groundwater, and the blanket discharge, respectively. Groundwater $\left[\mathrm{Br}^{-}\right.$] from $25 \mathrm{~cm}$ depth MINIPOINT samples $\left(0.3 \mu \mathrm{M}\right.$, collected prior to $\mathrm{Br}^{-}$injection) was used for $C_{g w}$ in March 2013. In July 2012, blanket corrections were much less sensitive to $C_{g w}$ (taken as zero in July 2012 because no preinjection groundwater samples were collected) because $C_{s w}$ was much higher than in March 2013 (50 $\mu \mathrm{M}$ versus $11 \mu \mathrm{M}$ ). With the groundwater fraction known from equation (4), the groundwater concentration for a solute of interest (e.g., nitrate) was calculated as:

$$
C_{g w}=\frac{C_{\text {blanket }}-\left(1-F_{g w}\right) C_{s w}}{F_{g w}}
$$

Results from equation (5) are referred to in this paper as "corrected blanket" concentrations. Corrected solute fluxes were calculated by multiplying corrected blanket $C_{g w}$ by corrected blanket discharge $v_{g w}=v_{\text {blanket }} F_{g w}$, where $v_{g w}$ is the flux from the blanket attributed to groundwater, and $v_{\text {blanket }}$ is the raw blanket flux calculated as the volumetric discharge measured from the blanket divided by the streambed 


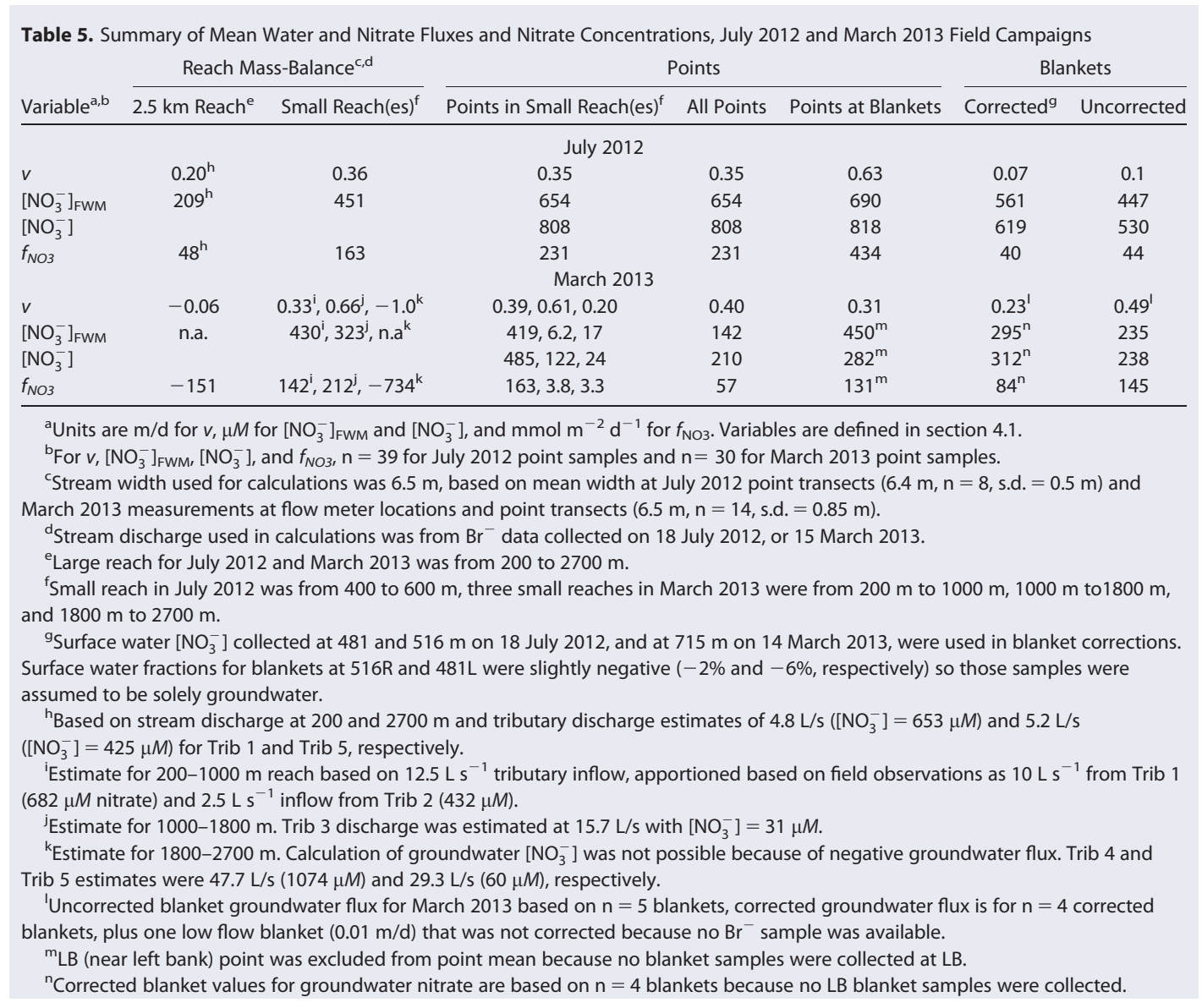

area covered by the blanket. Corrected solute fluxes represent solute fluxes exiting the surficial aquifer unaffected by biogeochemistry or mixing with stream water in the hyporheic zone, while uncorrected solute fluxes represent total fluxes across the top of the streambed.

\subsection{Sample Treatment and Analysis}

Stream water samples were filtered $(0.45 \mu \mathrm{M})$ in the field and stored in $20 \mathrm{~mL}$ LDPE vials at ambient temperature. Analysis of $\mathrm{Br}^{-}$was by ion chromatography at the Utah USGS Water Science Center in Salt Lake City, with estimated $3 \%$ analytical uncertainty. $\left[\mathrm{NO}_{3}^{-}\right]$was determined for July 2012 stream water samples by ion chromatography (supporting information). Stream water and groundwater samples from July 2012 were also analyzed for $\mathrm{Cl}^{-}$by ion chromatography at North Carolina State University.

With the exception of July 2012 stream water samples, all TDN, $\mathrm{NO}_{3}^{-}\left(\mathrm{NO}_{3}^{-}+\mathrm{NO}_{2}^{-}\right)$, and $\mathrm{NH}_{4}^{+}$samples were filtered $(0.70 \mu \mathrm{M}$ nominal, glass fiber filter), stored in $20 \mathrm{~mL}$ LDPE bottles, and kept on ice in the field or refrigerated. Samples to be analyzed for $\mathrm{NO}_{3}^{-}$and $\mathrm{NH}_{4}^{+}$were acidified to $\mathrm{pH}<2$ using $\mathrm{H}_{2} \mathrm{SO}_{4}$. Analysis for $\mathrm{NO}_{3}^{-}$ and $\mathrm{NH}_{4}^{+}$was by cadmium reduction colorimetric method in the North Carolina State University Soil Science Environmental and Agricultural Testing Service laboratory, with estimated 5\% analytical uncertainty. TDN analysis was by standard methods [Merriam et al., 1996] in the same laboratory.

Water samples for noble gas analysis ( $\mathrm{Xe}, \mathrm{Kr}, \mathrm{Ar}, \mathrm{Ne}, \mathrm{He}$ ) were collected in copper (Cu) tubes [AeschbachHertig and Solomon, 2013] and analyzed by mass spectrometry at the University of Utah Noble Gas Laboratory in Salt Lake City. Estimated uncertainties due to analytical and sampling methods for July $2012 \mathrm{Cu}$ tube samples were about $2 \%$ for $\mathrm{He}, 3 \%$ for $\mathrm{Ne}$, and $\mathrm{Ar}$, and $5 \%$ for $\mathrm{Kr}$ and $\mathrm{Xe} . \mathrm{N}_{2}$ was also measured from $\mathrm{Cu}$ tube samples, with estimated uncertainty of about $15 \%$. Uncertainty in concentrations for Cu tubes collected in March 2013 and from nearby wells (June 2013, see Figure 1b) was about 3\% for Ne, Ar, Kr, and Xe.

For a subset of the locations where Cu tube samples were collected, dissolved gas samples were also collected in glass septum bottles (no head space, sealed with rubber stoppers), stored on ice or refrigerated, and 

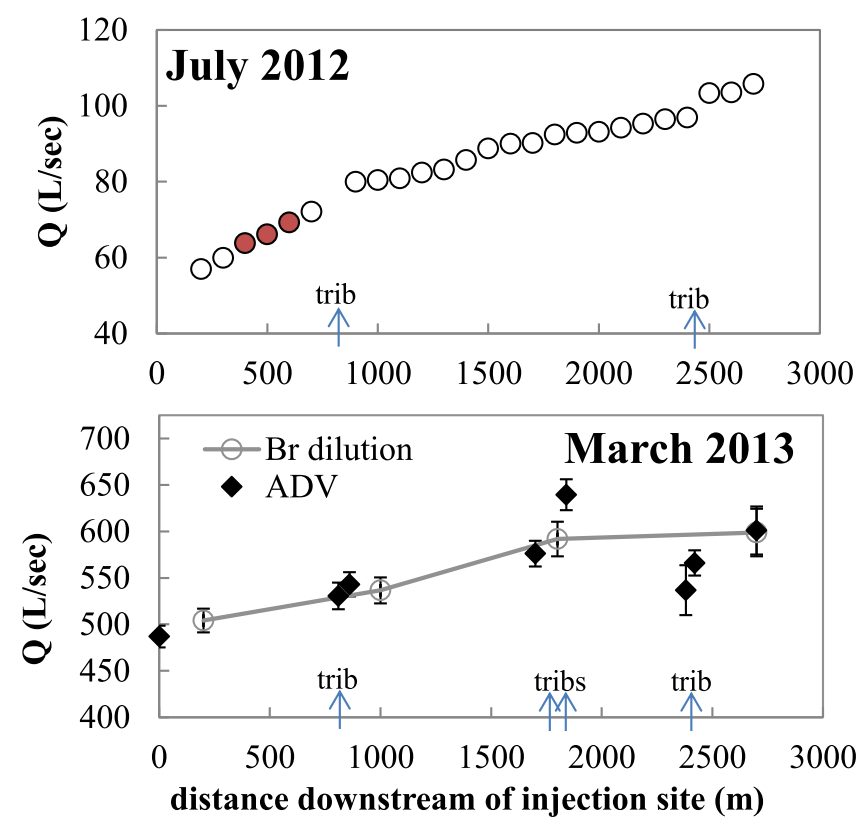

Figure 3. Stream discharge in July 2012 and March 2013. The locations of significant tributary inflows are indicated by arrows labeled "trib." Open circles in both figures show stream discharge calculated by $\mathrm{Br}^{-}$dilution. Filled circles in July 2012 highlight the $200 \mathrm{~m}$ small reach containing the $58 \mathrm{~m}$ point and blanket reach. Black diamonds in March 2013 show results of acoustic Doppler velocimeter (ADV) stream discharge measurements made the same day as $\mathrm{Br}^{-}$sampling Error bars show $95 \%$ confidence intervals. Uncertainties are not shown for July 2012 because the confidence interval was approximately the same size as the symbols. Stream water samples for $\mathrm{Br}^{-}$analysis were collected every $100 \mathrm{~m}$ in both July 2012 and March 2013, but in March $2013 v$ was so small relative to stream discharge that $\left[\mathrm{Br}^{-}\right]$did not decrease monotonically in the downstream direction (small random fluctuations indicated $100 \mathrm{~m}$ was too small a spatial scale for investigation of $v$ by $\mathrm{Br}^{-}$dilution). We calculated stream discharge in March 2013 based on stream water $\left[\mathrm{Br}^{-}\right]$at the autosampler sites, resulting in a coarser (800-900 m) spatial resolution compared to July 2012. analyzed for $\mathrm{CH}_{4}, \mathrm{CO}_{2}, \mathrm{~N}_{2}, \mathrm{O}_{2}$, and $\mathrm{Ar}$ at the USGS CFC Lab in Reston, VA. Reported precision for gases analyzed at the USGS CFC lab (http://water. usgs.gov/lab/dissolved-gas/lab/analytical_procedures/) was less than 1\% of the mean gas concentration in our July 2012 samples, except $\mathrm{CH}_{4}$, for which it was about $2 \%$.

Field measurements of groundwater temperature, dissolved oxygen (DO), $\mathrm{pH}$, and conductivity were made at each streambed sampling point using a YSI ProPlus Multiparameter Meter with flow cell prior to groundwater sample collection. Groundwater temperature was also measured at each point measurement location using a bimetal thermometer inserted $36 \mathrm{~cm}$ into the streambed.

\subsection{Nitrate Loss by Denitrification in Groundwater}

Excess dissolved $\mathrm{N}_{2}$ in groundwater, defined as the difference between total $\mathrm{N}_{2}$ and atmospherically-derived $\mathrm{N}_{2}$, was used to estimate the concentration of $\mathrm{N}_{2}$ from denitrification, $\left[\mathrm{N}_{2}-\right.$ den] [Vogel et al., 1981; Smith et al., 1991; Böhlke and Denver, 1995; Modica et al., 1998; Tesoriero et al., 2000; Tesoriero, 2005; Böhlke, 2002; Böhlke

et al., 2002; Böhlke et al., 2007; Green et al., 2008; Puckett et al., 2008]. Determination of [ $\mathrm{N}_{2}$-den] was based on (1) measured $\left[\mathrm{N}_{2}\right]$ in groundwater, (2) concentrations of noble gases in groundwater, and (3) estimated recharge temperature.

Atmospherically derived dissolved gas concentrations and the temperature of groundwater at recharge (i.e., at the water table) were estimated by fitting the Closed-System Equilibration (CE) model [Aeschbach-Hertig et al., 2000, 2008] to observed groundwater gas concentrations at two nearby well nests (Figure 1b; supporting information). The amount of atmospherically derived $\mathrm{N}_{2}$ in point and blanket samples was then determined by fitting the CE model to measured Ar and Ne concentrations in the point and blanket samples, assuming that recharge conditions for these samples matched the modeled conditions from the wells (supporting information). Xe and $\mathrm{Kr}$ were not used in the determination of [ $\mathrm{N}_{2}$-den] for point and blanket samples because those gases were injected into the stream as tracers, greatly elevating their concentrations in the stream and potentially in blanket samples.

From estimates of [ $\mathrm{N}_{2}$-den] we calculated $E_{\text {den, }}$, the percentage of recharge nitrate (nitrate entering the aquifer with recharge) that was removed by denitrification before groundwater discharge into West Bear Creek, for each groundwater point or blanket sample:

$$
E_{\text {den }}=\frac{2\left[\mathrm{~N}_{2} \text {-den }\right]}{\left[\mathrm{NO}_{3}^{-}\right]+2\left[\mathrm{~N}_{2}-\mathrm{den}\right]}=1-\frac{\left[\mathrm{NO}_{3}^{-}\right]}{\left[\mathrm{NO}_{3}^{-}\right]^{0}}
$$

where, on a molar basis, $\left[\mathrm{NO}_{3}^{-}\right]^{0}=\left[\mathrm{NO}_{3}^{-}\right]+2\left[\mathrm{~N}_{2}\right.$-den], assuming production of $\mathrm{N}_{2} \mathrm{O}$ from denitrification was negligible compared to production of $\mathrm{N}_{2}$ [e.g., Fox et al., 2014] and that nitrification and ammonification in groundwater were negligible. 


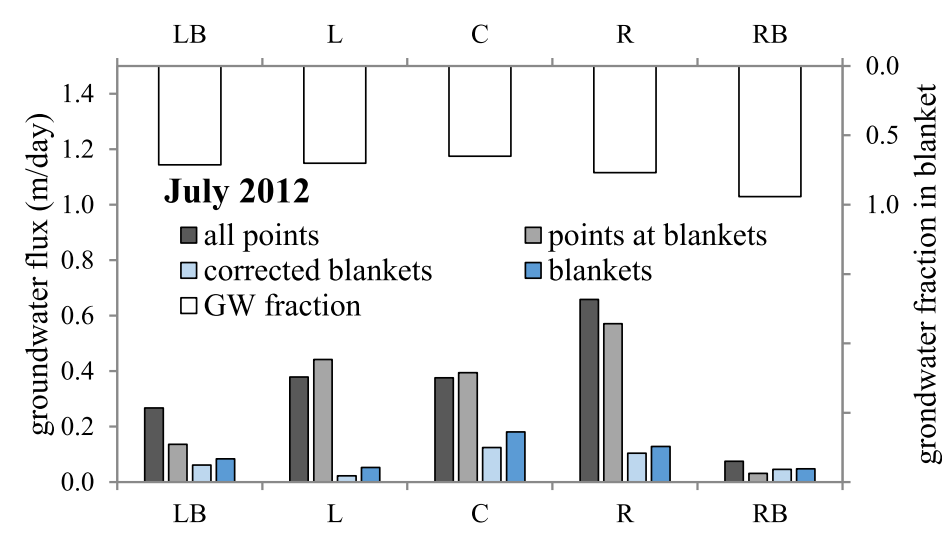

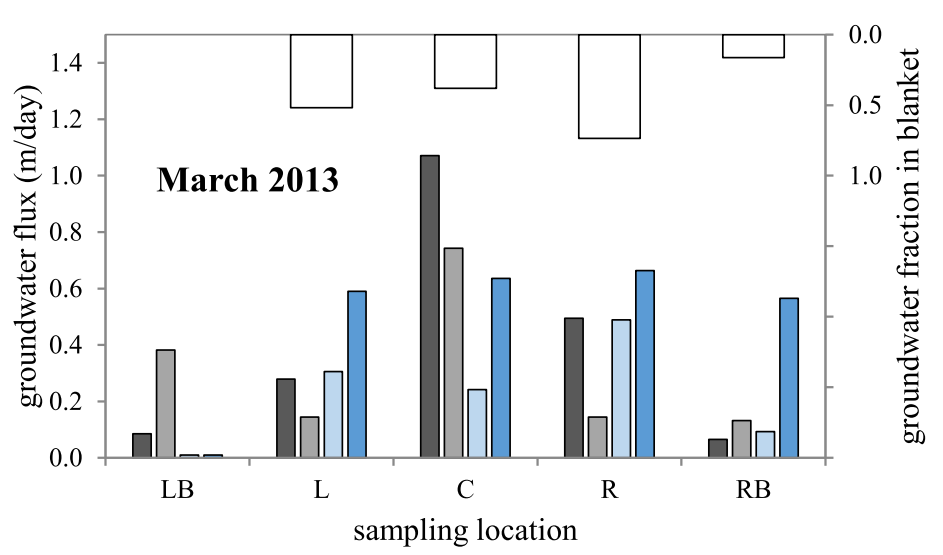

Figure 4. Lateral (across the channel) variability in groundwater flux from point and blanket measurements in July 2012 and March 2013. Results are arranged from the perspective of someone facing downstream. Surface water (SW) fractions were calculated with equation (4).

\subsection{Uncertainty Estimates}

For reach mass-balance results, analytical uncertainties (e.g., in $\left[\mathrm{Br}^{-}\right]$or $\left.\left[\mathrm{NO}_{3}^{-}\right]\right)$and measurement uncertainties (e.g., variability in stream width measurements made during the field campaigns) were propagated through equations (1-3) using standard methods [e.g., Taylor, 1997; Kirkup and Frenkel, 2006] to determine uncertainties at the $95 \%$ confidence level for $v,\left[\mathrm{NO}_{3}^{-}\right]_{\mathrm{FWM}}$, and $f_{\mathrm{NO} 3}$.

Uncertainties in individual blanket estimates of groundwater flux are found in Solder [2014]. We used the reported coefficient of variation (CoV) from Monte Carlo simulations [Solder, 2014, Appendix J] to estimate $95 \%$ confidence intervals ( $2 \mathrm{CoV}$ ) for blanket discharge. Uncertainties for individual point measurements were calculated according to Kennedy et al. [2007] and Genereux et al. [2008].

The variability in $\mathrm{N}$ concentrations and mean fluxes for point and blanket approaches were calculated as the standard error (SE $=\sigma / \mathrm{n}^{0.5}$ ) multiplied by the Student's $t$ statistic for $\mathrm{n}-1$ degrees of freedom at the 95\% confidence level, after Kennedy et al. [2007]. These confidence intervals are effectively controlled by the range of concentrations or fluxes over the spatial area where samples were collected (i.e., they reflect mainly spatial variability, rather than uncertainty from measurement error). Uncertainty in flow-weighted mean concentrations $\left(\left[\mathrm{NO}_{3}^{-}\right]_{\mathrm{FWM}}\right)$ for points and blankets were determined by propagating error through the equation $\left[\mathrm{NO}_{3}^{-}\right]_{\mathrm{FWM}}=\Sigma\left(f_{\mathrm{NO}_{3}} / \Sigma v\right)$. The use of the mixing model (equation (4)) was assumed to have negligible effect on corrected blanket FWM uncertainty.

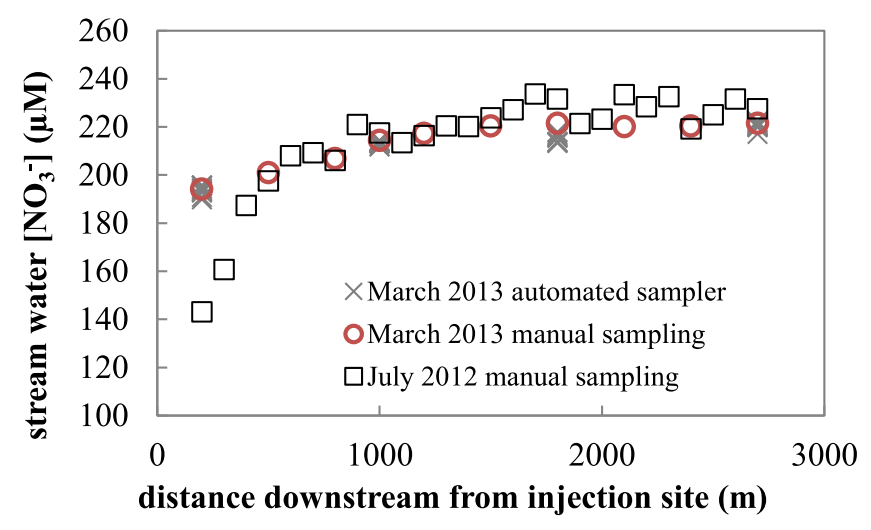

Figure 5. Stream water nitrate concentrations for July 2012 and March 2013 as a function of distance downstream of the tracer injection site. Automated sampler symbols show the range of concentrations over roughly a $12 \mathrm{~h}$ period $(n=11-12)$.
Uncertainty in [ $\mathrm{N}_{2}$-den] from point and blanket data was estimated from $\left[\mathrm{N}_{2}\right]$ modeling using upper and lower limits for recharge temperature and recharge gas concentrations (details are found in supporting information).

\section{Results and Discussion}

\subsection{Overview}

Streambed point, streambed blanket, and reach mass-balance results were compared for the two field campaigns (Table 5) to answer the question of whether the approaches gave fundamentally different pictures of the fate 


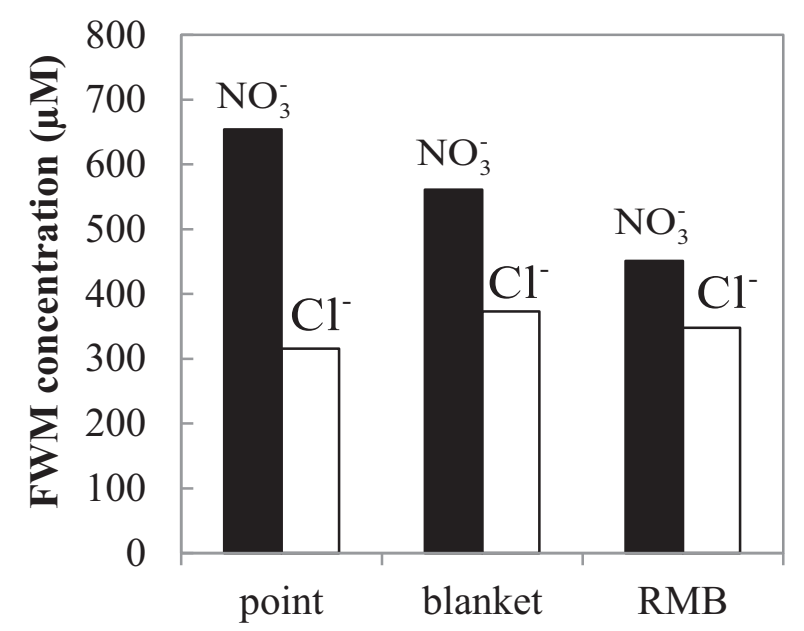

Figure 6. Flow-weighted mean concentrations of nitrate and chloride for the three sampling approaches, July 2012. Reach mass-balance (RMB) concentrations were based on a $200 \mathrm{~m}$ reach containing the $58 \mathrm{~m}$ reach where streambed points and blankets were sampled. of agricultural nitrate in the surficial aquifer. We focus primarily on the following comparisons:

1. Streambed blanket results (corrected and uncorrected, equations (4 and 5)) versus results from streambed points (all points, and the subset of points immediately adjacent to blankets).

2. Reach mass-balance estimates for the full $2.5 \mathrm{~km}$ study reach in West Bear Creek, and for smaller reaches, versus results for streambed points and blankets. In July 2012, the "small reach" for reach massbalance was a $200 \mathrm{~m}$ section of West Bear Creek that contained the $58 \mathrm{~m}$ reach with the eight point transects and two blanket transects. For March 2013, the $2.5 \mathrm{~km}$ large reach was split into three small reaches (200-1000 $\mathrm{m}, 1000-1800 \mathrm{~m}$, and

1800-2700 m), each of which contained two streambed point transects; the 200-1000 m reach also contained the single March 2013 blanket transect.

\subsection{Groundwater Flux}

Estimates of groundwater flux $(v)$ from the streambed point, streambed blanket (corrected for stream water intrusion), and reach mass-balance (bromide dilution) approaches suggested gaining conditions (Figures 3 and 4 ) and were in good agreement (Table 5), with two exceptions. First, corrected blanket $v$ was low in July $2012(0.07 \mathrm{~m} / \mathrm{d})$, especially compared to points adjacent to blankets $(0.63 \mathrm{~m} / \mathrm{d})$. Second, in March 2013 the reach mass-balance approach suggested the downstream portion of the stream (1800-2700 m) was a losing reach (the sum of tributary inputs was greater than the input calculated from $\mathrm{Br}^{-}$dilution), while

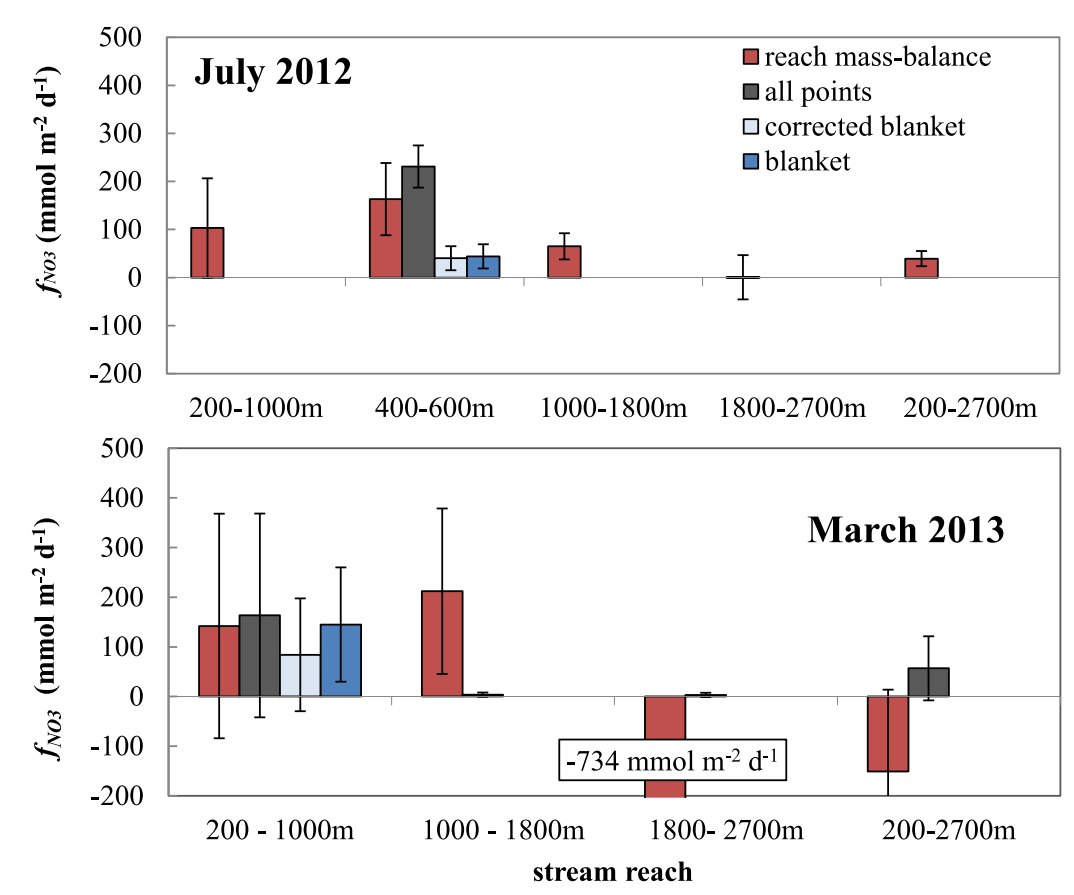

Figure 7. Nitrate fluxes from groundwater to West Bear Creek for (a) July 2012 and (b) March 2013. The large negative (stream-to-groundwater) reach mass-balance flux for $1800-2700 \mathrm{~m}$ is indicated by a label and the bar is not shown to full scale. The short bar $\left(0.5 \mathrm{mmol} \mathrm{m}^{-2}\right.$ $\mathrm{d}^{-1}$ ) for 1800-2700m in July 2012 was a reach mass-balance measurement. 


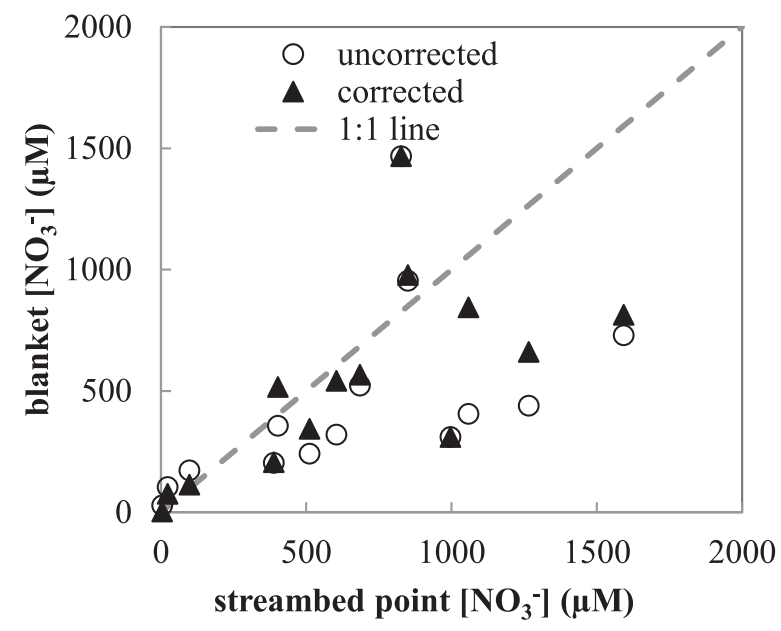

Figure 8. Streambed blanket $\left[\mathrm{NO}_{3}^{-}\right]$(uncorrected and corrected) versus $\left[\mathrm{NO}_{3}^{-}\right]$from streambed points. streambed point measurements in the same reach indicated gaining conditions. Examples of good agreement included points and reach mass-balance in July 2012 (0.35 and $0.36 \mathrm{~m} / \mathrm{d}$, respectively), and corrected blankets, points at blankets, and reach massbalance in March 2013 (0.23, 0.31, and $0.33 \mathrm{~m} / \mathrm{d}$, respectively).

Stream discharge $200 \mathrm{~m}$ downstream of the tracer injection site was about 10 times larger in March 2013 than in July 2012 (Figure 3), but $v$ was fairly similar between the two campaigns (Table 5) and clearly not 10 times different. Thus, stream discharge increased by mechanisms not directly related to groundwater flux through the bed of the main channel, such as shallow lateral discharge to small ditches and other tributaries, increased output from small surface reservoirs (Figure 1b), and perhaps expanding seepage faces on the steep banks. This is highly relevant to understanding the $\left[\mathrm{NO}_{3}^{-}\right]_{\mathrm{FWM}}$ and $f_{\mathrm{NO} 3}$ results under dry (July 2012) and wet (March 2013) conditions.

Both point and blanket (corrected and uncorrected) results showed higher groundwater flux toward the center of the stream and lower flux near the stream banks (Figure 4), though the greater number of point than blanket observations (69 versus 15) gives more statistical confidence in the point trend. While points and blankets both showed higher $v$ near the center of the channel, $v$ estimates from adjacent blankets (corrected) and points were not highly correlated (for blanket $v$ versus point $v$, slope $=-0.06, R^{2}=0.04, p=0.49, n=15$ ). In a similar previous comparison of $v$ from point measurements and more traditional seepage meters in West Bear Creek, Kennedy et al. [2010] found slope $=0.24$ and $R^{2}=0.27$, with $n=53$. Kennedy et al. [2010] found the ratio of mean $v$ from seepage meters to mean $v$ from points was about 0.7 , much higher than our blanket-topoint ratio in July 2012 (about 0.1 for corrected blankets) but the same as the ratio for March 2013 (0.7), suggesting that the efficiency of the blankets in March was similar to that of traditional seepage meters. The exact reason for the closer point-blanket agreement in March 2013 compared to July 2012 is not clear [Solder, 2014], a number of factors may have differed slightly in March and played a role (more careful installation and possibly better seal of the blanket edges to the streambed, greater care and slightly less disturbance while working around and sampling from the blankets, etc.). March 2013 results suggest the streambed blankets have potential as devices for accurately measuring groundwater discharge.

\subsection{Flow-Weighted Mean Nitrate Concentration in Aquifer Discharge}

All three sampling approaches showed groundwater $\left[\mathrm{NO}_{3}^{-}\right]$elevated well above the estimated $71 \mu M$ background $\left[\mathrm{NO}_{3}^{-}\right.$] for undeveloped areas in the United States. [Dubrovsky et al., 2010]. In general, stream water $\left[\mathrm{NO}_{3}^{-}\right]$increased in the downstream direction, particularly from 0 to $600 \mathrm{~m}$ (Figure 5), suggesting aquifer discharge of nitrate during both July 2012 and March 2013.

Results from July 2012 showed $\left[\mathrm{NO}_{3}^{-}\right]_{\mathrm{FWM}}$ decreased with increasing sampling integration scale and potential for influence by channel processes: $654 \pm 18 \mu \mathrm{M}$ from point measurements, $561 \pm 73 \mu \mathrm{M}$ from blankets (corrected for stream water intrusion), and $451 \pm 316 \mu M$ from reach mass-balance. The point sampling $31-36 \mathrm{~cm}$ deep in the streambed reached below the thin hyporheic zone (generally $<10 \mathrm{~cm}$ deep based on vertical solute profiles in the streambed, section 5.4) to capture groundwater not affected by removal of nitrate in the channel (uptake or denitrification). Samples collected from the seepage blankets represented groundwater that had interacted with the hyporheic zone and the top surface of the streambed beneath the blanket, both potential sites of denitrification in biofilms. $\left[\mathrm{NO}_{3}^{-}\right]_{\mathrm{FWM}}$ from reach mass-balance (equation (3)) represents groundwater that is fully mixed with the stream water and subject to the full suite of possible in-stream nitrate removal processes (hyporheic and in-channel). The trend in $\left[\mathrm{NO}_{3}^{-}\right]_{\mathrm{FWM}}$ suggests nitrate removal in the streambed and channel, and contrasts with the lack of a trend in the flow-weighted concentrations of the conservative ion $\mathrm{Cl}^{-}(315-373 \mu M$, Figure 6). 

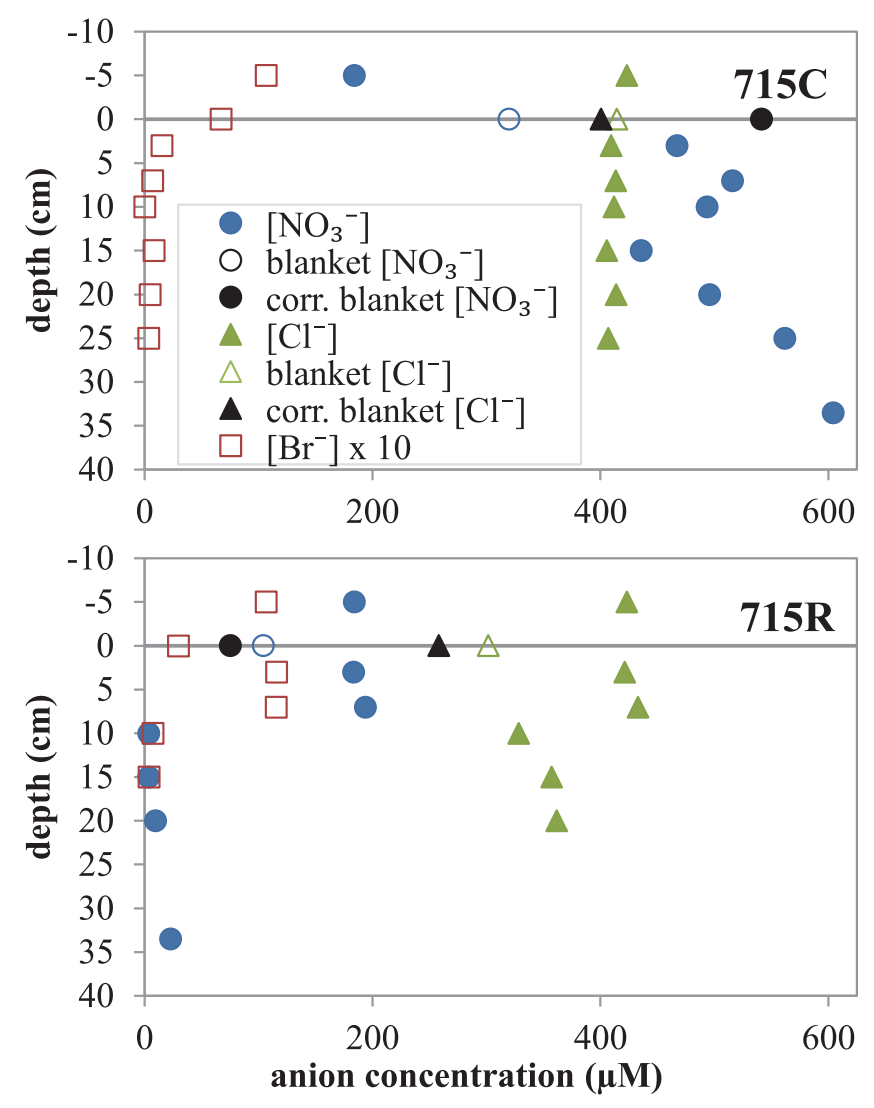

Figure 9. Vertical profiles of streambed chemistry, $715 \mathrm{~m}$ transect, center (C) and right side (R) of channel, in West Bear Creek. Concentrations plotted on the streambed surface (depth $=0$ ) represent blanket samples, either uncorrected (symbols with no fill) or corrected for stream water mixing (black-filled symbols). Stream water concentrations are plotted above the streambed surface (negative depth), and values plotted at $33.5 \mathrm{~cm}$ depth are from piezomanometer samples (31-36 cm screen). All other concentrations are from a USGS MINIPOINT sampler. $\left[\mathrm{Br}^{-}\right]$has been multiplied by a factor of 10 for plotting. data was higher than the $f_{N O 3}$ estimate from reach mass-balance $\left(163 \mathrm{mmol} \mathrm{m}^{-2} \mathrm{~d}^{-1}\right)$ in the $200 \mathrm{~m}$ reach that contained the points and blankets (Figure 7). The difference $\left(68 \mathrm{mmol} \mathrm{m}^{-2} \mathrm{~d}^{-1}\right)$ is a loss rate comparable to published estimates for in-channel denitrification [Böhlke et al., 2004; Laursen and Seitzinger, 2005; Birgand et al., 2007] and nitrate retention (removal) in stream sediments and channels [e.g., Stelzer et al., $2011 \mathrm{a}$ ]. Groundwater $f_{\mathrm{NO} 3}$ from corrected blanket data was very low in July $2012\left(40 \mathrm{mmol} \mathrm{m} \mathrm{m}^{-2} \mathrm{~d}^{-1}\right.$ ) due to unrealistically low blanket estimates of $v$, though there is evidence of nitrate removal in/on streambed sediments near blankets independent of $f_{\mathrm{NO} 3}$ : blanket $\left[\mathrm{NO}_{3}^{-}\right]$was typically lower than point $\left[\mathrm{NO}_{3}^{-}\right]$, even after correction for surface water in blankets (Figure 8), and some vertical profiles of streambed chemistry suggested denitrification in the streambed (Figure 9). March 2013 results are also consistent with nitrate removal in the shallow streambed sediments: $f_{\mathrm{NO} 3}$ from corrected blanket data was $47 \mathrm{mmol} \mathrm{m}{ }^{-2} \mathrm{~d}^{-1}$ lower than $f_{\mathrm{NO} 3}$ from adjacent point sampling (84 versus $131 \mathrm{mmol} \mathrm{m} \mathrm{m}^{-2} \mathrm{~d}^{-1}$, Table 5).

Given the potential for nitrate removal in the streambed and channel, $f_{\mathrm{NO}}$ from reach mass-balance is likely a lower limit on the nitrate flux leaving the aquifer, at least under low-flow conditions (July 2012). During wetter high-discharge conditions in March 2013, $f_{\mathrm{NO}}$ from reach mass-balance was only slightly lower than that from points for the 200-1000 $\mathrm{m}$ reach (142 versus $163 \mathrm{mmol} \mathrm{m}^{-2} \mathrm{~d}^{-1}$ ), and higher than from points for the $1000-1800 \mathrm{~m}$ reach (212 versus $3.8 \mathrm{mmol} \mathrm{m}^{-2} \mathrm{~d}^{-1}$, respectively). The higher $f_{\mathrm{NO} 3}$ by reach massbalance compared to points for the 1000-1800 $\mathrm{m}$ reach, and similarity in $f_{\mathrm{NO}_{3}}$ from the two approaches in the 200-1000 $\mathrm{m}$ reach, is likely because the reach mass-balance approach integrated shallow transient high-nitrate flow paths that were important during high flow in March 2013, such as shallow discharge to small transient tributaries and groundwater discharge through seepage faces on streambanks [e.g., Böhlke 

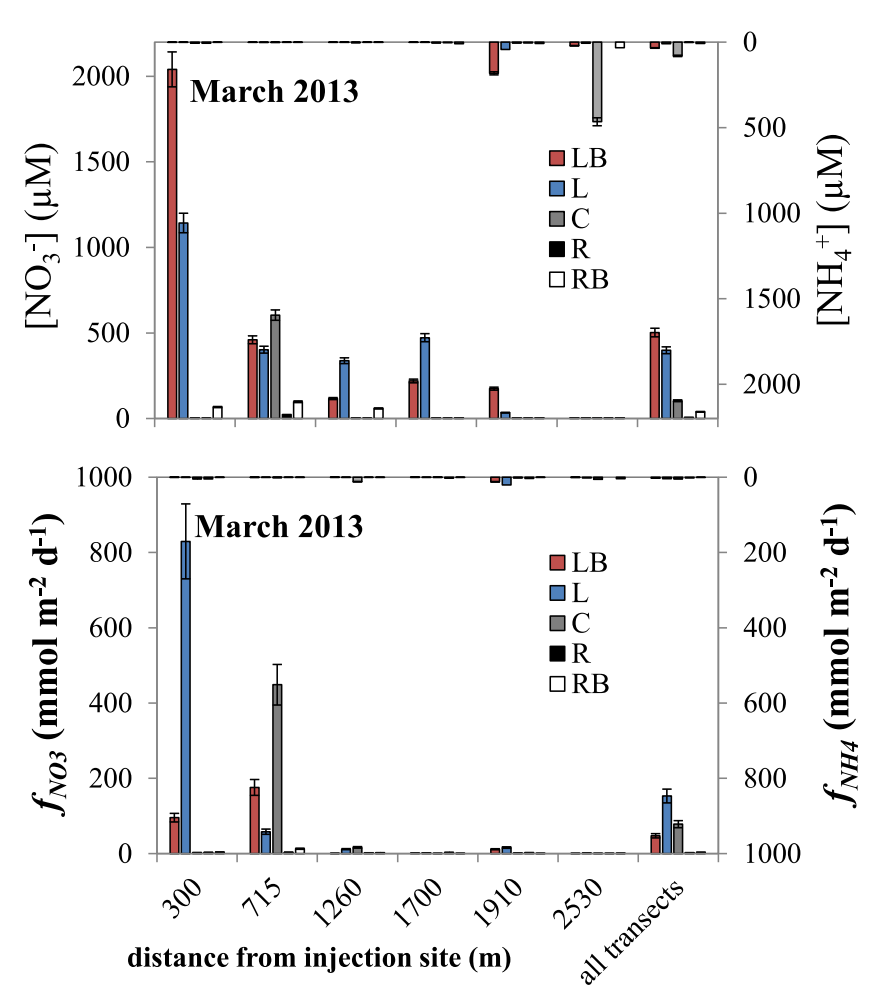

Figure 10. Lateral variation across the channel in groundwater nitrate and ammonium on six different point sampling transects in March 2013: (a) concentration, and (b) flux. Nitrate bars run upward from the bottom of the graphs and refer to the vertical scale on the left, ammonium bars run downward from the top and refer to the vertical scale on the right. Bars labeled "all transects" show means for all transects. Error bars show 5\% analytical uncertainty for concentrations and mean uncertainty (12\%) for fluxes.

nitrate concentrations along the left bank (the mean for LB was significantly higher than for C, R (right), and $\mathrm{RB})$, where the tree buffer was less well developed than on the right bank. The map of nitrate flux is dominated by 3-4 hotspots with high seepage rates (Figure 11c; given the large variability only $L$ and RB had significantly different means), illustrating the importance of flow-weighting measured concentrations to determine nitrate discharge from the groundwater system. Similarly, in March 2013, the sampling location with greatest $\left[\mathrm{NO}_{3}^{-}\right]$(2041 $\mu \mathrm{M}$, Figure 10a) was not the location with the greatest $f_{\mathrm{NO}}$ (Figure 10b).

In general, such findings from point sampling (relationships among nitrate flux, nitrate concentration, water flux, and spatial location) cannot be obtained from reach mass-balance, and might be possible with seepage blankets but would likely be affected by denitrification in (1) the upper part of the streambed and/or (2) the small space between the blanket and the top of the streambed (water resides in this space briefly in between discharging from the streambed and reaching the discharge port of the blanket). We cannot definitively separate nitrate loss in these two zones. However, the average residence time of water in the space between the blanket and the top of the streambed was only about $15-20 \%$ of the total residence time between the depth of point sampling and the blanket outlet port. The relatively short residence time beneath the blanket (where the ratio of water volume to reactive sediment surface area is much higher than in the streambed sediments) suggests that blankets were unlikely to cause a strong bias in measured nitrate concentrations.

\subsection{Amount of Denitrification and Initial Nitrate Concentrations 5.5.1. Dissolved Gases: Degassing and Excess Air}

$\left[\mathrm{N}_{2}\right.$-den] was estimated by modeling based on (1) measured [ $\left.\mathrm{N}_{2}\right],[\mathrm{Ar}]$, and [Ne] in groundwater, and (2) an estimated recharge temperature $\left(12.3^{\circ} \mathrm{C}\right)$ from noble gas thermometry at nearby well nests. We computed the concentrations of dissolved gases for water in equilibrium with air (WEA) at $12.3^{\circ} \mathrm{C}$, which are the theoretical concentrations of dissolved atmospheric gases at recharge. In reality, many groundwater samples 


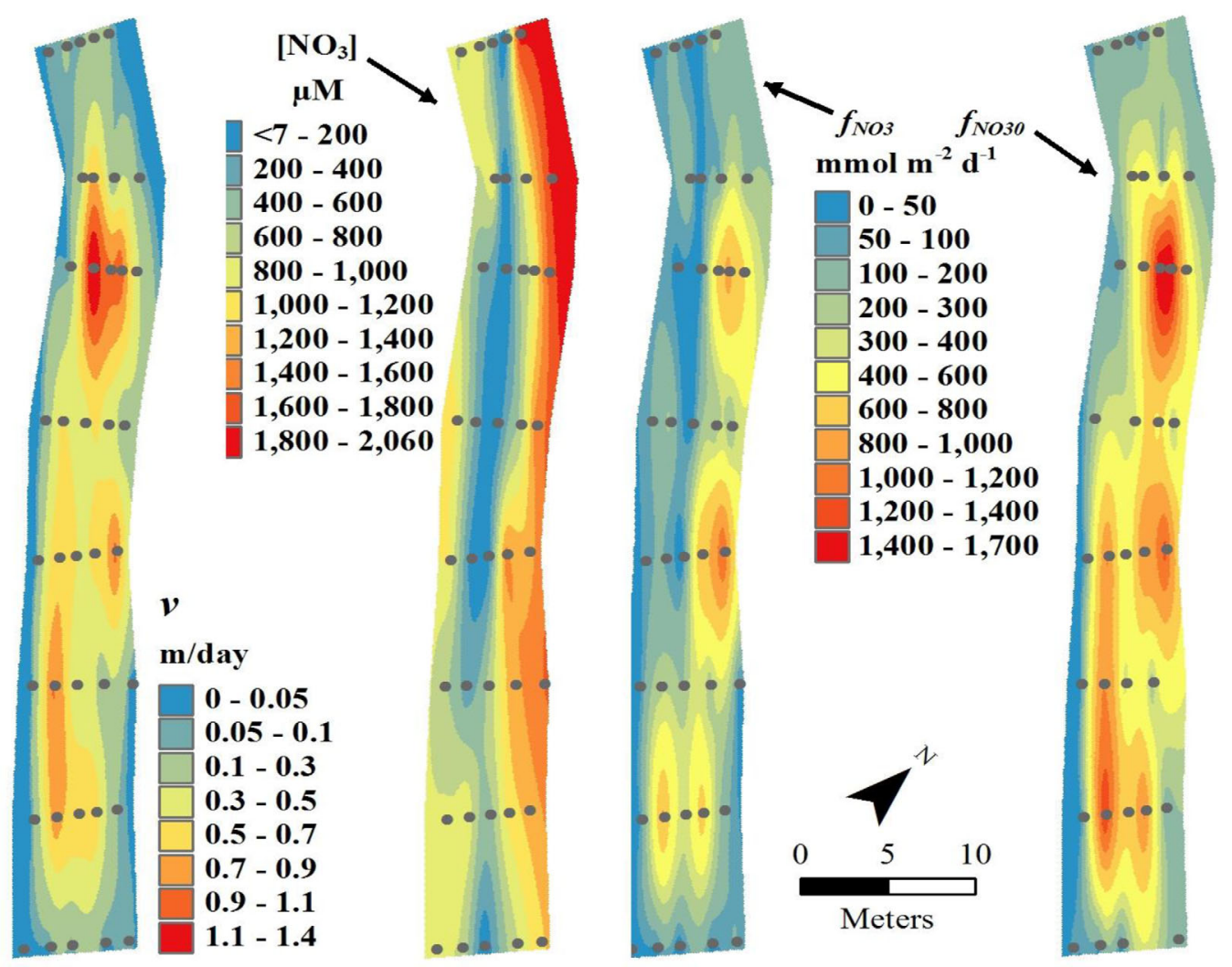

Figure 11. Streambed maps for 466-524 m, West Bear Creek, July 2012, showing water flux v, groundwater [ $\left[\mathrm{NO}_{3}^{-}\right]$, nitrate flux $f_{\mathrm{NO}}$, and $f_{\mathrm{NO} 3}{ }^{O}$ (i.e., what nitrate flux would have been if no denitrification had occurred in the surficial aquifer). Maps are oriented with streamflow from top to bottom, and thus the left side of the channel is on the right side of each map. The maps were created using a multiquadric radial basis function in ESRI ArcMap $^{\mathrm{TM}} 10.0$, with settings of 8 and 0.0 for the anisotropy and kernel parameters, respectively. Groundwater $v$ or $\left[\mathrm{NO}_{3}^{-}\right]$values that fell exactly on the upper limit of any bin were included in that bin.

have gas concentrations greater than WEA, or "excess air," typically due to dissolution of trapped air bubbles near the water table [e.g., Heaton and Vogel, 1981]. In other cases, groundwater samples have gas concentrations lower than WEA, suggesting that "degassing" has occurred, typically when dissolved gases partition into bubbles in the groundwater after production of biogenic gases such as $\mathrm{N}_{2}, \mathrm{CH}_{4}$, or $\mathrm{CO}_{2}[$ Visser et al., 2007; Aeschbach-Hertig et al., 2008]. The percent excess (or depletion) of [Ne] relative to WEA (denoted

\begin{tabular}{|c|c|c|c|c|}
\hline \multirow[b]{2}{*}{ Variable $^{a}$} & \multicolumn{2}{|c|}{ Blanket } & \multicolumn{2}{|c|}{ Point } \\
\hline & Uncorrected & Corrected & At Blankets & $\mathrm{All}^{\mathrm{b}}$ \\
\hline \multicolumn{5}{|c|}{ July 2012} \\
\hline$\left[\mathrm{NO}_{3}^{-}\right]_{\mathrm{FWM}}^{0}$ & 802 & 1086 & 1284 & 1300 \\
\hline$\left[\mathrm{NO}_{3}^{-}\right]^{0}$ & 908 & 1096 & 1312 & 1453 \\
\hline$f_{\mathrm{NO}^{\circ}}{ }^{\circ}$ & 79 & 78 & 809 & 477 \\
\hline$\left[\mathrm{N}_{2} \text {-den }\right]_{\mathrm{FWM}}$ & 177 & 262 & 297 & 319 \\
\hline$E_{d e n}$ & $44 \%$ & $48 \%$ & $46 \%$ & $49 \%$ \\
\hline \multicolumn{5}{|c|}{ March 2013} \\
\hline$\left[\mathrm{NO}_{3}^{-}\right]_{\mathrm{FWM}}^{0}$ & 384 & 660 & 783 & 519 \\
\hline$\left[\mathrm{NO}_{3}^{-}\right]^{0}$ & 385 & 817 & 756 & 629 \\
\hline$f_{\mathrm{NO} 3}{ }^{3}$ & 237 & 188 & 228 & 235 \\
\hline$\left[\mathrm{N}_{2} \text {-den }\right]_{\mathrm{FWM}}$ & 75 & 184 & 167 & 188 \\
\hline$E_{d e n}$ & $39 \%$ & $55 \%$ & $43 \%$ & $72 \%$ \\
\hline
\end{tabular}
as $\Delta \mathrm{Ne}$ ) was used as an indicator of the magnitude of excess air (positive $\Delta \mathrm{Ne}$ ) or degassing (negative $\Delta \mathrm{Ne}$ ). In July, most point samples (31 of 36 samples) were degassed (negative $\Delta \mathrm{Ne}$ ), while in March 2013 only 14 of 29 were degassed, likely because the March sampling temperature was cooler. Lower groundwater temperatures inhibit biogenic production of gases in the streambed and also increase gas solubility.

\subsubsection{Denitrification in the Surficial Aquifer: Streambed-Based}

Measurements

Applying the reach mass-balance approach to stream water $\left[\mathrm{N}_{2}\right]$ showed that the method had low sensitivity to the denitrification signal associated with 

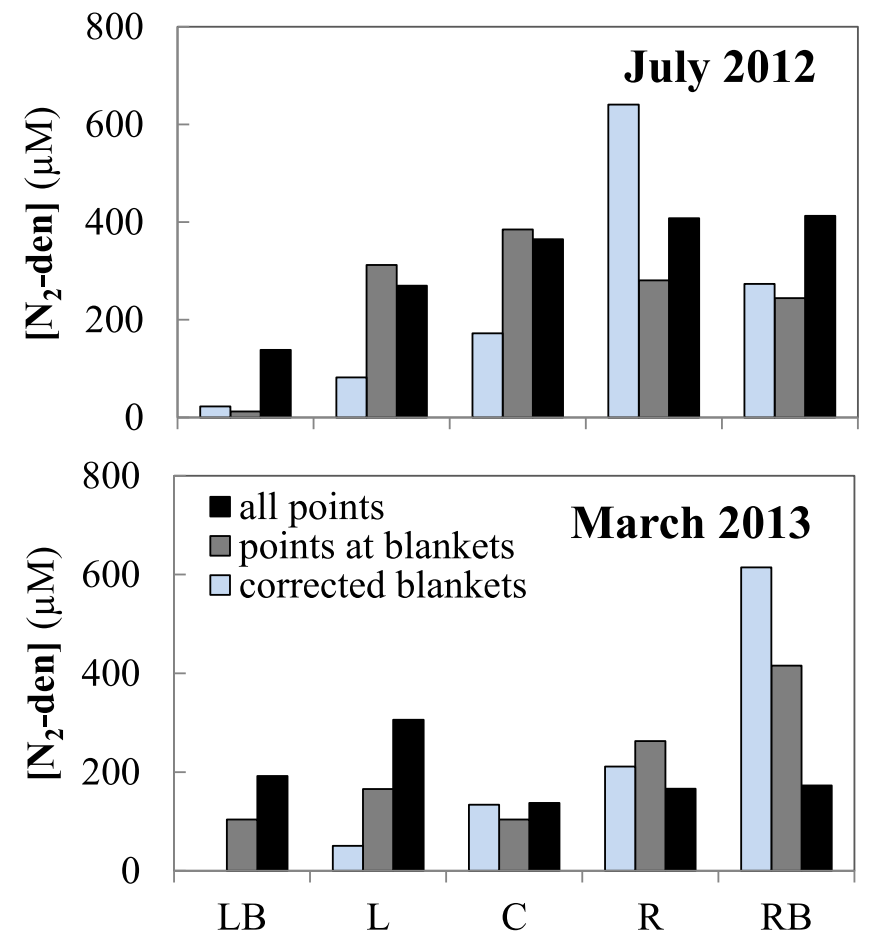

Figure 12. Cross-channel patterns of [ $\mathrm{N}_{2}$-den] from point and blanket samples, July 2012 and March 2013. Gray bars show [ $\mathrm{N}_{2}$-den] from points sampled adjacent to blankets. Each black bar is the mean of 6-8 point samples (July) or 4-6 point samples (March); each gray or pale blue bar represents 1-2 samples. "No data" indicates where no blanket sample was collected. aquifer discharge of excess $\mathrm{N}_{2}$ to the stream, mainly because excess $\mathrm{N}_{2}$ from denitrification was a small fraction (typically $<3 \%$ ) of the total $\mathrm{N}_{2}$ flux within a given stream reach, and thus highly uncertain (supporting information).

Blanket and point groundwater $\left[\mathrm{N}_{2}-\right.$ den] results from both July 2012 and March 2013 consistently showed that denitrification had occurred in the surficial aquifer. Flow-weighted mean $\left[\mathrm{N}_{2}-\right.$ den] values, $\left[\mathrm{N}_{2}-\text { den }\right]_{\mathrm{FWM}}$, were roughly 200-300 $\mu M$ (Table 6), suggesting loss of twice that much nitrate (400-600 $\mu M)$ in the groundwater system. $E_{d e n}$, the fraction of initial nitrate lost by denitrification, was about $50 \%$, in agreement with a previous estimate based on less extensive dissolved gas sampling and modeling [Kennedy et al., 2009a]. Point and corrected blanket results yielded similar $\left[\mathrm{N}_{2} \text {-den }\right]_{\mathrm{FWM}}$ and $E_{\text {den }}$, with the corrected blanket results being slightly higher in March 2013; thus, the two streambed sampling approaches gave very similar pictures of the large subsurface nitrate sink (an

important ecosystem service that protects surface water quality), with the blanket sampling perhaps also capturing some additional nitrate loss in/on the streambed in March 2013 (though the difference from points was small, [ $\mathrm{N}_{2}$-den] $]_{\mathrm{FWM}}$ of 184 for corrected blankets versus $167 \mu \mathrm{M}$ for points at the blankets).

\subsubsection{Spatial Patterns of Denitrification}

Point data suggested some relationships between denitrification and location within the watershed, with which the less-numerous blanket data were generally consistent. For example, there was higher [ $\mathrm{N}_{2}$-den] in groundwater beneath the right side (March 2013) or the right side and center (July 2012) of the stream (Figure 12), possibly related to a generally wider wooded riparian buffer with fewer gaps on that side. Also, greater denitrification was associated with greater degassing and anoxia in groundwater (Figure 13), at least in July 2012 (this trend was not observed in March 2013, when there were fewer blanket samples and a much greater spatial spread, $>2200 \mathrm{~m}$, in point samples). In July 2012, anoxic conditions were observed at the point sampling sites where degassing was most prominent, i.e., where $\Delta \mathrm{Ne}$ was most negative (Figure 13), suggesting biogenic production of gases $\left(\mathrm{N}_{2}, \mathrm{CH}_{4}, \mathrm{CO}_{2}\right)$ could have caused the degassing. Elevated degassing on the right side of the stream is consistent with previous observations of lower [Ar] there, interpreted in past work as an indication of higher recharge temperature [Kennedy et al., 2009a] but now thought to instead be due to degassing.

In July $2012,\left[\mathrm{NO}_{3}^{-}\right]^{0}$ results from the closely spaced point sampling transects followed a symmetric "centerlow" lateral pattern across the channel (Figure 13), consistent with similar recharge of nitrate into the groundwater system on both sides of the channel near the July reach (Figure 1). In a companion paper, we show that greater groundwater age coincides with lower $\left[\mathrm{NO}_{3}^{-}\right]^{0}$ beneath the center of the stream [Gilmore et al., 2016], consistent with previous findings [Kennedy et al., 2009a]. In March 2013, at the point sample transects at and downstream of $1260 \mathrm{~m}$ (Figure 1), $\left[\mathrm{NO}_{3}^{-}\right]^{0}$ was not symmetric across the channel but was instead lower on the right and right bank positions ( $R$ and $R B$ ), most likely due to the extensive forested areas (without fertilizer application) on the right side of the stream, downstream of $1000 \mathrm{~m}$ (Figure 1). Thus, both the streambed point and blanket sampling have the potential to relate current groundwater quality beneath the channel to spatial and historical aspects of land and $\mathrm{N}$ use. 

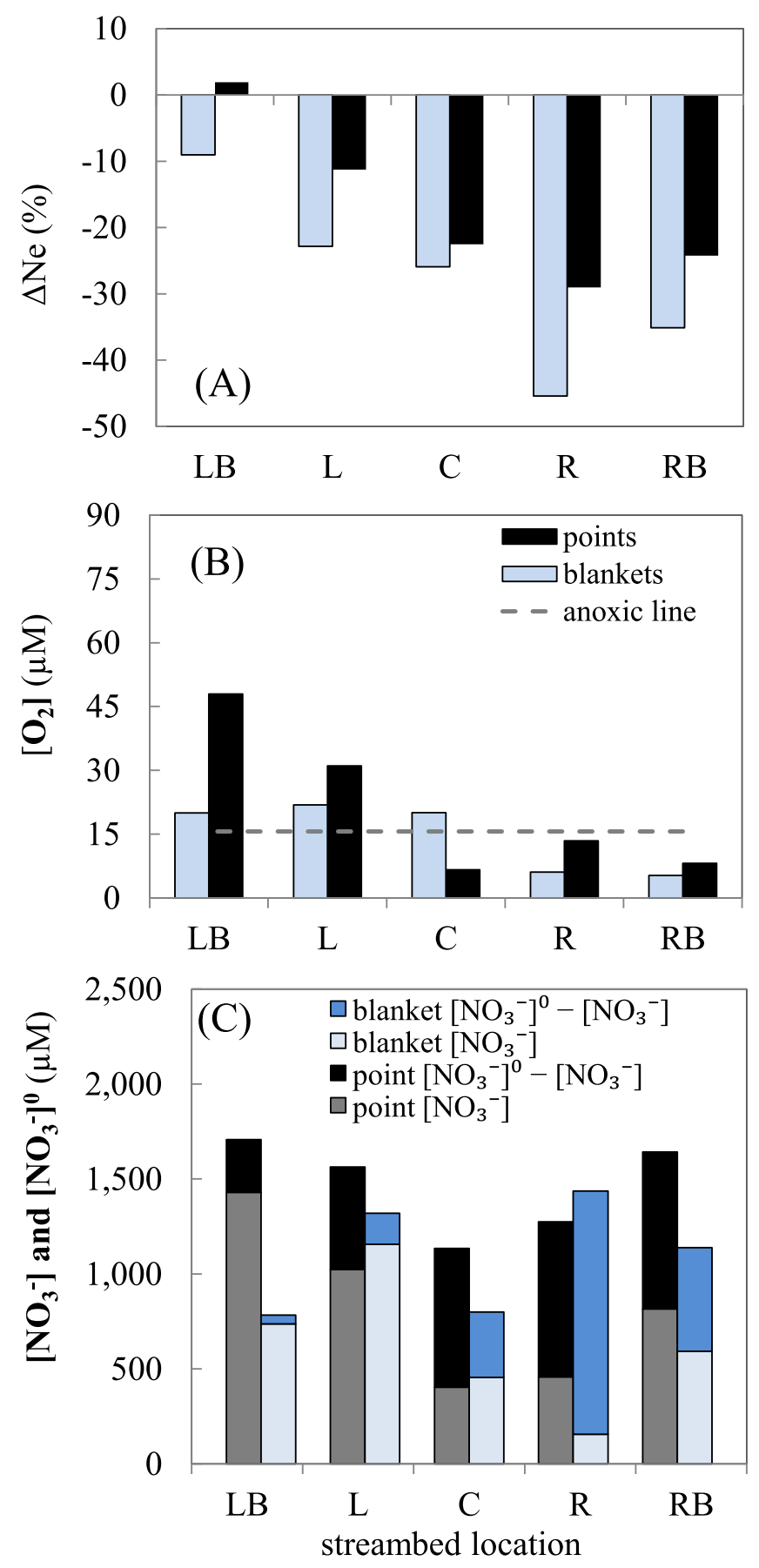

Figure 13. Cross-channel patterns of (a) $\Delta \mathrm{Ne}$, (b) $\left[\mathrm{O}_{2}\right]$, and (c) nitrate in point and corrected blanket samples, July 2012. Gray bars (c) show measured nitrate from point samples, and black bars show nitrate removed in the aquifer $\left(\left[\mathrm{NO}_{3}^{-}\right]^{0}\right.$ $-\left[\mathrm{NO}_{3}^{-}\right]=2\left[\mathrm{~N}_{2}-\right.$ den $]$ ). Light blue bars (c) show measured nitrate from blanket samples, and dark blue bars show nitrate removed in the aquifer. The total height of each gray plus black stacked bar, and each light blue plus dark blue stacked bar, is the mean value of $\left[\mathrm{NO}_{3}^{-}\right]^{0}$ at the given location. Blanket results are corrected for surface water mixing, except for the $\left[\mathrm{O}_{2}\right]$ data (stream water $\left[\mathrm{O}_{2}\right]$ was not measured in July, but it seems that any correction of blanket $\left[\mathrm{O}_{2}\right]$ data would have been very small, given that all $\left[\mathrm{O}_{2}\right]$ means were below or near the $16 \mu M$ typical threshold for anoxic conditions, shown as a dashed line in graph b).

\subsubsection{In-Channel Denitrification Versus Denitrification in the Surficial Aquifer}

While this study focused on elucidating differences among the point, blanket, and reach mass-balance sampling approaches, those differences create some synergies regarding the study of denitrification, as suggested earlier with respect to $\left[\mathrm{NO}_{3}^{-}\right]_{\mathrm{FWM}}$ and $f_{\mathrm{NO} 3}$. Based on the July 2012 point data, the $646 \mu M$ average nitrate reduction in the surficial aquifer from $1300 \mu M$ (Table 6) to $654 \mu M$ (Table 5) represents about half the initial nitrate in the aquifer. Roughly an additional third of the nitrate entering the streambed was removed in the streambed sediments and/or channel, based on the difference between $\left[\mathrm{NO}_{3}^{-}\right]_{\mathrm{FWM}}$ from the streambed points $(654 \mu M)$ and reach mass-balance (451 $\mu M$, Table 5). In March 2013, data showed $\left[\mathrm{NO}_{3}^{-}\right]_{\mathrm{FWM}}^{0}=783 \mu M$ and $\left[\mathrm{NO}_{3}^{-}\right]_{\mathrm{FWM}}=450 \mu \mathrm{M}$ at the points adjacent to blankets, and $\left[\mathrm{NO}_{3}^{-}\right]_{\mathrm{FWM}}=295$ $\mu M$ from the blankets, suggesting almost half of the initial nitrate $(783-450=333 \mu \mathrm{M})$ was removed in the surficial aquifer while roughly an additional third of the remaining nitrate $(450-295=155 \mu M)$ was removed in the streambed. Thus, simultaneous use of approaches with different measurement support scales and degrees of channel influence seems to have potential for separating denitrification in the unconfined aquifer from that occurring in the streambed and/or channel.

\section{Summary and Conclusions}

In the (typical) absence of a network of numerous spatially distributed multilevel samplers or well nests, stream beds and channels (as places of groundwater discharge) may be used to access groundwater of different age and recharge location to assess the fate of contaminant nitrate in an aquifer. There are relatively few field methods that can be reliably deployed for such sampling, three of which were 
assessed and compared in this study of an agricultural coastal plain watershed: streambed point measurements, streambed seepage blankets, and reach mass-balance. The three approaches were applied during 3-4 day field campaigns in July 2012 and March 2013 that included a number of novel aspects, especially the simultaneous application and comparison of the three approaches (point, blanket, and reach massbalance sampling), on a widespread and biogeochemically complex groundwater contaminant (nitrate), using a variety of sampling designs at both high and flow conditions (stream discharge $\sim 50 \mathrm{~L} / \mathrm{s}$ in July 2012 and $500 \mathrm{~L} / \mathrm{s}$ in March 2013). Also, the streambed seepage blanket is a new tool [Solder, 2014] never used before at any field site. The attempt to quantify groundwater $\left[\mathrm{N}_{2}\right.$-den] at the reach scale by reach mass-balance was novel, albeit ultimately ambiguous because the groundwater signal was not large enough after mixing with surface water. The piezomanometer has the potential to become a standard method/tool, though to our knowledge it has only appeared in a few previous papers [Kennedy et al., 2008, 2009a, 2009b, 2010]. Also, to our knowledge these previous papers, the current paper, a companion paper [Gilmore et al., 2016], and Browne and Guldan [2005] are the only ones reporting measurements of groundwater chemistry or age coupled with head gradient and hydraulic conductivity measurements at all the same points and times, a critical and necessary combination of measurements for flow-weighting spatially variable groundwater solute concentrations. All three methods used are capable of yielding flow-weighted solute concentrations in discharging groundwater, which is central to computing aquifer discharge and its effects on surface water quality.

At low flow in July 2012, estimates of groundwater flux from the aquifer to the stream were very similar between point sampling and the $\mathrm{Br}^{-}$dilution work needed for reach-mass balance. At higher stream flow in March 2013, groundwater flux was again similar between point sampling and $\mathrm{Br}^{-}$dilution for two $800 \mathrm{~m}$ long reaches (the 200-1000 $\mathrm{m}$ reach, and 1000-1800 $\mathrm{m}$ reach). In the more complex 1800-2700 $\mathrm{m}$ reach point sampling indicated groundwater input but $\mathrm{Br}^{-}$dilution in conjunction with stream discharge data from an ADV suggested a losing reach (Table 5). Blanket and adjacent point data gave similar discharge in March 2013 (Table 5), in better agreement than in July 2012. The seepage blanket seems to have potential for the study of water and chemical fluxes at the groundwater-surface water interface, and merits further development.

Comparison of the three sampling methods during low stream flow showed a trend related to the biogeochemistry of nitrate, while high-flow comparison showed the impact of transient hydrologic flow paths to the stream. The July 2012 trend in $\left[\mathrm{NO}_{3}^{-}\right]_{\mathrm{FWM}}$, points $>$ blankets $>$ reach mass-balance (Table 5), was consistent with greater loss of nitrate (likely by denitrification) by stronger streambed and/or channel influence on the sampling method (reach mass-balance sampling has the greatest degree of such influence, point sampling the least, and blankets an intermediate level). In July 2012 , the situation was similar for $f_{\mathrm{NO}_{3}}$ in that the estimate from point sampling was greater than that from reach mass-balance.

However, at high flow (March 2013), the methods compared differently for $\left[\mathrm{NO}_{3}^{-}\right]_{\mathrm{FWM}}$ and $f_{\mathrm{NO} 3}$ : reach massbalance shifted from giving lower $\left[\mathrm{NO}_{3}^{-}\right]_{\mathrm{FWM}}$ and $f_{\mathrm{NO} 3}$ than point sampling at low flow to giving equal or higher values at high flow (Table 5). The change is likely linked to shallow lateral transient flow, discharging at high flow on banks above the waterline and into small tributaries. These results are also consistent with the fact that groundwater flux through the streambed of the main channel in the $200-1000 \mathrm{~m}$ reach was nearly the same between the two sampling campaigns even though stream discharge was about $10 \times$ larger in March 2013 (transient flow paths must explain the higher stream discharge).

Interestingly, in the upstream part of the study stream (200-1000 m), point sampling and reach massbalance gave different $\left[\mathrm{NO}_{3}^{-}\right]_{\mathrm{FWM}}$ and $f_{\mathrm{NO}}$ at low flow, when they were responding to more or less the same inputs (groundwater flow paths to the streambed in the main channel, no shallow transient flow paths), and similar results at high flow, when they were responding to different inputs (only groundwater flow paths for point sampling, groundwater plus shallow lateral transient flow paths for reach mass-balance). The different results at low flow were likely due to both (1) denitrification in the streambed and channel, and (2) greater channel influence on reach mass-balance sampling than point sampling; removing just one of these factors, the denitrification (by focusing on $\mathrm{Cl}^{-}$rather than $\mathrm{NO}_{3}^{-}$), removes the sensitivity of flow-weighted mean solute concentration to sampling method (Figure 6). This underscores the importance of understanding the inherent differences in these sampling methods when investigating fluxes (especially for reactive chemical species) at the groundwater-surface water interface. 
It also suggests the importance of matching the method to the question. For a study focused on nitrate flux exiting the surficial aquifer, streambed point sampling may be the best approach (least channel influence) in a streambed that allows for insertion and use of sampling probes (Table 1). Reach mass-balance may or may not give similar results to points, depending on the flow condition and potential differences between the nitrate concentration in shallow soil and $\left[\mathrm{NO}_{3}^{-}\right]_{\mathrm{FWM}}$. If the focus is instead on nitrate flux into the stream, point sampling in the streambed may underestimate this flux at high flow (if nitrate is high in the shallow soil) and overestimate it at low flow (if there is nitrate removal in the streambed). Reach mass-balance may represent a better approach, at least at high flow. Our blanket sampling at low flow gave anomalously low seepage rates but in principle this method may be the best of the three for determining nitrate flux across the top of the streambed, if the flow measurement can be done more accurately as it seemed to have been in March 2013.

Of course, the complexity of $\mathrm{N}$ biogeochemistry is what complicates the matter; the choice among the three methods does not matter nearly as much or at all for more simple solutes (e.g., Figure 6). However, the differences among the methods also present an opportunity to gather a fuller picture of the groundwatersurface water exchange of nitrate. For example, point and blanket sampling shows that about half the nitrate entering the groundwater system near West Bear Creek was lost by denitrification in the aquifer before discharge to the stream, documenting a large subsurface nitrate sink that protects surface water quality. Of the nitrate that reaches the streambed, an additional third of that is lost relatively quickly in the upper streambed (top $36 \mathrm{~cm}$ ) and/or after a short $(\sim 100 \mathrm{~m})$ transit in the stream channel. The difference between the nitrate discharge rate from the groundwater system (point data) and the nitrate input rate to the stream (blanket or reach mass-balance data) was $47-68 \mathrm{mmol} \mathrm{m}^{-2} \mathrm{~d}^{-1}$ (Table 5), a number that falls within the published range of in-channel nitrate removal (retention) rates. Simultaneous application of point sampling with blankets, other seepage meters, or reach mass-balance may represent a viable approach to constraining the magnitude of channel nitrate removal rates.

Initial nitrate at recharge, $\left[\mathrm{NO}_{3}^{-}\right]^{0} \mathrm{FWM}$, and percent nitrate loss by denitrification in the surficial aquifer, $E_{\text {den }}$ were not reliably determined at the reach mass-balance scale, but points and blankets gave similar and seemingly reliable estimates for both parameters (corrected blanket values were slightly lower than point values in March 2013), even when blanket nitrate flux was low because $v$ was too low (Table 6).

Accounting for degassing (loss of dissolved gases from groundwater due to bubble formation) was important for interpreting the amount of denitrification from both point and blanket dissolved gas data (Figure 13). Where degassing is anticipated (e.g., in contaminated agricultural areas), it may be beneficial to collect streambed groundwater samples for dissolved gas analysis during colder weather and/or deeper in the streambed to guard against degassing.

The point and blanket approaches yield more spatial information than reach mass-balance, and our results suggest linkages between land use and groundwater nitrate contamination (Figures 10-13). Low groundwater $\left[\mathrm{NO}_{3}^{-}\right]$was observed in the center of the stream (Figure 11) due to the presence there of older and less contaminated water likely recharged relatively far from the stream [Gilmore et al., 2016]. The highest $\left[\mathrm{NO}_{3}^{-}\right]$was on the left side of the stream where the riparian buffer was generally less well-developed, and likely reflects agricultural practices close to the stream (Figure 10). High groundwater $\left[\mathrm{NH}_{4}^{+}\right]$was observed only on the left and center of the downstream portion of the study reach, and was likely related to animal operations in the recharge area near that section of the stream. Low $\left[\mathrm{NO}_{3}^{-}\right]^{0}$ (initial nitrate concentration in groundwater) occurred on the right side of the stream, downstream of the $1200 \mathrm{~m}$ stream location, where forested land use dominated the recharge area (Figure 1). Thus, streambed point and blanket sampling go beyond total rates for the two main nitrate sinks (denitrification and discharge to surface water) to allow insights with a spatial context related to land use, a clear advantage over the reach mass-balance approach.

A secondary question is how to arrange streambed point (or blanket) sampling, e.g., closely versus widely spaced transects (Figure 1). In West Bear Creek, using both arrangements gave both a broad picture of a range of conditions along the stream (e.g., the transition from all nitrate upstream to nitrate plus ammonium downstream, the different land use effects described in section 5.5.3), and a more detailed picture of lateral variation and spatial variability in nitrate discharge and denitrification in a small area (Figure 11), including the influence of relative groundwater age (center versus sides of the channel) and riparian buffers (less developed on the left). 
Overall, did the three methods (points, blankets, reach mass-balance) give a fundamentally different picture of the fate of nitrate in the surficial aquifer? Each sampling approach showed nitrate contamination in groundwater discharge, and point and blanket sampling gave very similar pictures of the amount of denitrification in the aquifer (Table 6), but there is a need to properly interpret the differences in results among the methods based on the characteristics of each method. For example, when points miss transient lateral flows above the waterline, that may be a problem if the goal is quantifying total nitrate inputs to the stream system at high flow, but a benefit if the goal is quantifying the nitrate discharge from the aquifer (it means aquifer discharge can be quantified at the streambed under a wide range of flow conditions, including transient high flow after precipitation events). The three approaches are a complementary set of methods for looking at the broad picture of the fate of nitrate in the surficial aquifer, including the nitrate discharge to surface water and denitrification in the aquifer, and linked surface water processes such as nitrate removal in the streambed and channel.

\section{Acknowledgments}

Data used for tables and figures are available from the corresponding author upon request. This project was funded by National Science Foundation under Awards EAR1045162 to North Carolina State University and EAR-1045134 to the University of Utah. The authors gratefully acknowledge assistance with field work: Matt Burnette and Scott Becker (both NC State) in July 2012 and March 2013, and Kyle AveniDeforge (NC State), Casey Kennedy (USDA-ARS), Matt Webb (Arcadis U.S.), and Vic Heilweil and James Marlowe (USGS) in March 2013.

\section{References}

Aeschbach-Hertig, W., and D. K. Solomon (2013), Noble gas thermometry in groundwater hydrology, in The Noble Gases as Geochemical Tracers (eBook), edited by P. Burnard, pp. 81-122, Springer, Heidelberg.

Aeschbach-Hertig, W., F. Peeters, U. Beyerle, and R. Kipfer (2000), Palaeotemperature reconstruction from noble gases in ground water taking into account equilibration with entrapped air, Nature, 405(6790), 1040-1044, doi:10.1038/35016542.

Aeschbach-Hertig, W., H. El-Gamal, M. Wieser, and L. Palcsu (2008), Modeling excess air and degassing in groundwater by equilibrium partitioning with a gas phase, Water Resour. Res., 44, W08449, doi:10.1029/2007WR006454.

Alley, W. M., T. E. Reilly, and L. O. Franke (1999), Sustainability of ground-water resources, U.S. Geol. Surv. Circ., 1186, 86 pp. [Available at http://pubs.usgs.gov/circ/circ1186/.]

Angier, J. T., and G. W. McCarty (2008), Variations in base-flow nitrate flux in a first-order stream and riparian zone1, J. Am. Water Resour. Assoc., 44(2), 367-380, doi:10.1111/j.1752-1688.2007.00153.x.

Bachman, L. J., B. D. Lindsey, J. Brakebill, and D. S. Powers (1998), Ground-water discharge and base-flow nitrate loads to nontidal streams, and their relation to a hydrogeomorphic classification of the Chesapeake Bay watershed, Middle Atlantic Coast, U.S. Geo1. Surv. Water Resour. Invest. Rep., 98-4059, 152 pp.

Baulch, H. M., J. J. Venkiteswaran, P. J. Dillon, and R. Maranger (2010), Revisiting the application of open-channel estimates of denitrification, Limnol. Oceanogr. Methods, 8, 202-215, doi:10.4319/lom.2010.8.202.

Bennett, J. P., and R. E. Rathbun (1972), Reaeration in open-channel flow, U.S. Geol. Surv. Prof. Pap., PP-737, 86 pp. [Available at http://pubs. er.usgs.gov/publication/pp737.]

Birgand, F., R. W. Skaggs, G. M. Chescheir, and J. W. Gilliam (2007), Nitrogen removal in streams of agricultural catchments: A literature review, Crit. Rev. Environ. Sci. Technol., 37(5), 381-487, doi:10.1080/10643380600966426.

Böhlke, J. K. (2002), Groundwater recharge and agricultural contamination, Hydrogeol. J., 10, 153-179, doi:10.1007/s10040-001-0183-3.

Böhlke, J. K., R. Wanty, M. Tuttle, G. Delin, and M. Landon (2002), Denitrification in the recharge area and discharge area of a transient agricultural nitrate plume in a glacial outwash sand aquifer, Minnesota, Water Resour. Res., 38(7), 1105, doi:10.1029/2001WR000663.

Böhlke, J. K., and J. M. Denver (1995), Combined use of groundwater dating, chemical, and isotopic analyses to resolve the history and fate of nitrate contamination in two agricultural watersheds, Atlantic Coastal Plain, Maryland, Water Resour. Res., 31(9), 2319-2339, doi: 10.1029/95WR01584.

Böhlke, J. K., J. W. Harvey, and M. A. Voytek (2004), Reach-scale isotope tracer experiment to quantify denitrification and related processes in a nitrate-rich stream, midcontinent United States, Limnol. Oceanogr., 49(3), 821-838.

Böhlke, J. K., M. E. O'Connell, and K. L. Prestegaard (2007), Ground water stratification and delivery of nitrate to an incised stream under varying flow conditions, J. Environ. Qual., 36(3), 664-680, doi:10.2134/jeq2006.0084.

Böhlke, J. K., R. C. Antweiler, J. W. Harvey, A. E. Laursen, L. K. Smith, R. L. Smith, and M. A. Voytek (2009), Multi-scale measurements and modeling of denitrification in streams with varying flow and nitrate concentration in the upper Mississippi River basin, USA, Biogeochemistry, 93(1-2), 117-141. doi:10.1007/s10533-008-9282-8.

Bouwer, H., and R. C. Rice (1968) Review of methods for measuring and predicting seepage, in Proceedings of 2nd Seepage Symposium, pp. 115-I20, U.S. Dep. Agric. Rep. Agric. Res. Surv., 41-147.

Browne, B. A., and N. M. Guldan (2005), Understanding long-term baseflow water quality trends using a synoptic survey of the ground water-surface water interface, Central Wisconsin, J. Environ. Qual., 34(3), 825-835.

Burns, D. A. (1998), Retention of $\mathrm{NO}_{3}^{-}$in an upland stream environment: A mass balance approach, Biogeochemistry, 40(1), 73-96, doi: 10.1023/A:1005916102026.

Cey, E. E., D. L. Rudolph, G. W. Parkin, and R. Aravena (1998), Quantifying groundwater discharge to a small perennial stream in southern Ontario, Canada, J. Hydrol., 210(1-4), 21-37, doi:10.1016/S0022-1694(98)00172-3.

Chestnut, T. J., and W. H. McDowell, W. H. (2000), C and N dynamics in the riparian and hyporheic zones of a tropical stream, Luquillo Mountains, Puerto Rico, J. N. Am. Benthol. Soc., 19(2), 199-214, doi:10.2307/1468065.

Clow, D. W., L. Schrott, R. Webb, D. H. Campbell, A. Torizzo, and M. Dornblaser (2003), Ground water occurrence and contributions to streamflow in an alpine catchment, Colorado front range, Ground Water, 41(7), 937-950, doi:10.1111/j.1745-6584.2003.tb02436.x.

Corbett, D. R., J. E. Cable, E. A. Shinn, C. D. Reich, and T. D. Hickey (2003), Seepage meters and advective transport in coastal environments: Comments on "Seepage Meters and Bernoulli's Revenge" by E.A. Shinn, C.D. Reich, and T.D. Hickey. 2002. "Estuaries" 25:126-132, Estuaries, 26(5), 1383-1387.

Diaz, R. J., and R. Rosenberg (1995), Marine benthic hypoxia: A review of its ecological effects and the behavioural responses of benthic macrofauna, Oceanogr. Mar. Biol. Annu. Rev., 33, 245-303.

Dubrovsky, N. M., et al. (2010), The quality of our nation's water-nutrients in the nation's streams and groundwater, 1992-2004, U.S. Geol. Surv. Circ., 1350, 174 pp. [Available at http://water.usgs.gov/nawqa/nutrients/pubs/circ1350/.]

Duff, J. H., F. Murphy, C. C. Fuller, F. J. Triska, J. W. Harvey, and A. P. Jackman (1998), A mini drive point sampler for measuring pore water solute concentrations in the hyporheic zone of sand-bottom streams, Limnol. Oceanogr., 43(6), 1378-1383, doi:10.4319/lo.1998.43.6.1378. 
Duff, J. H., A. J. Tesoriero, W. B. Richardson, E. A. Strauss, and M. D. Munn (2008), Whole-stream response to nitrate loading in three streams draining agricultural landscapes, J. Environ. Qual., 37(3), 1133-1144, doi:10.2134/jeq2007.0187.

Edwards, T. K., and G. D. Glysson (1999), Field methods for measurement of fluvial sediment, U.S. Geol. Surv.Tech. Water Resour. Invest., TWRI3-C2, 89 pp. [Available at http://pubs.usgs.gov/twri/twri3-c2/pdf/TWRI_3-C2.pdf.]

Fox, R. J., T. R. Fisher, A. B. Gustafson, T. E. Jordan, T. M. Kana, and M. W. Lang (2014), Searching for the missing nitrogen: Biogenic nitrogen gases in groundwater and streams, J. Agric. Sci., suppl. S1, 96-106, doi:10.1017/S0021859614000070.

Genereux, D. P., and H. F. Hemond (1992), Determination of gas exchange rate constants for a small stream on Walker Branch Watershed, Tennessee, Water Resour. Res., 28(9), 2365-2374, doi:10.1029/92WR01083.

Genereux, D. P., H. F. Hemond, and P. J. Mulholland (1993), Use of radon-222 and calcium as tracers in a three-end-member mixing model for streamflow generation on the West Fork of Walker Branch Watershed, J. Hydrol., 142(1-4), 167-211, doi:10.1016/00221694(93)90010-7.

Genereux, D. P., S. Leahy, H. Mitasova, C. D. Kennedy, and D. R. Corbett (2008), Spatial and temporal variability of streambed hydraulic conductivity in West Bear Creek, North Carolina, USA, J. Hydrol., 358(3-4), 332-353, doi:10.1016/j.jhydrol.2008.06.017.

Gilmore, T. E. (2015), Groundwater transit times and the fate of aquifer nitrate: Observations from sampling in stream channels and well nests in an agricultural watershed, North Carolina, USA, PhD dissertation, 226 pp., Dep. of Biol. and Agric. Eng., N. C. State Univ., Raleigh. [Available at http://repository.lib.ncsu.edu/ir/bitstream/1840.16/10373/1/etd.pdf.]

Gilmore, T. E., D. P. Genereux, D. K. Solomon, and J. E. Solder (2016), Groundwater transit time distribution and mean from streambed sampling in an agricultural coastal plain watershed, North Carolina, USA, Water Resour. Res., 52, doi:10.1002/2015WR017600.

Green, C. T., L. J. Puckett, J. K. Böhlke, B. A. Bekins, S. P. Phillips, L. J. Kauffman, J. M. Denver, and H. M. Johnson (2008), Limited occurrence of denitrification in four shallow aquifers in agricultural areas of the United States, J. Environ. Qual., 37(3), 994-1009, doi:10.2134/ jeq2006.0419.

Gu, C., G. M. Hornberger, J. S. Herman, and A. L. Mills (2008), Influence of stream-groundwater interactions in the streambed sediments on $\mathrm{NO}_{3}{ }^{-}$flux to a low-relief coastal stream, Water Resour. Res., 44, W11432, doi:10.1029/2007WR006739.

Harvey, J. W., and C. C. Fuller (1998), Effect of enhanced manganese oxidation in the hyporheic zone on basin-scale geochemical mass balance, Water Resour. Res., 34(4), 623-636, doi:10.1029/97WR03606.

Hayashi, M., and D. O. Rosenberry (2002), Effects of ground water exchange on the hydrology and ecology of surface water, Ground Water, 40(3), 309-316, doi:10.1111/j.1745-6584.2002.tb02659.x.

Heaton, T. H. E., and J. C. Vogel (1981), "Excess air" in groundwater, J. Hydrol., 50, 201-216, doi:10.1016/0022-1694(81)90070-6.

Hemond, H. F., and A. P. Duran (1989), Fluxes of $\mathrm{N}_{2} \mathrm{O}$ at the sediment-water and water-atmosphere boundaries of a nitrogen-rich river, Water Resour. Res., 25(5), 839-846, doi:10.1029/WR025i005p00839.

Hesslein, R. H. (1976), An in situ sampler for close interval pore water studies, Limnol. Oceanogr., 21(6), 912-914.

Holmes, R. M. (2000), Chapter 5: The importance of ground water to stream ecosystem function, in Streams and Ground Waters, edited by J. B. Jones and P. J. Mulholland, pp. 137-148, Academic, San Diego.

Kalbus, E., F. Reinstorf, and M. Schirmer (2006), Measuring methods for groundwater-surface water interactions: A review, Hydrol. Earth Syst. Sci., 10(6), 873-887.

Kennedy, C. D., D. P. Genereux, D. R. Corbett, and H. Mitasova (2007), Design of a light-oil piezomanometer for measurement of hydraulic head differences and collection of groundwater samples, Water Resour. Res., 43, W09501, doi:10.1029/2007WR005904.

Kennedy, C. D., D. P. Genereux, H. Mitasova, D. R. Corbett, and S. Leahy (2008), Effect of sampling density and design on estimation of streambed attributes, J. Hydrol., 355, 164-180, doi:10.1016/j.jhydrol.2008.03.018.

Kennedy, C. D., D. P. Genereux, D. R. Corbett, and H. Mitasova (2009a), Relationships among groundwater age, denitrification, and the coupled groundwater and nitrogen fluxes through a streambed, Water Resour. Res., 45, W09402, doi:10.1029/2008WR007400.

Kennedy, C. D., D. P. Genereux, D. R. Corbett, and H. Mitasova (2009b), Spatial and temporal dynamics of coupled groundwater and nitrogen fluxes through a streambed in an agricultural watershed, Water Resour. Res., 45, W09401, doi:10.1029/2008WR007397.

Kennedy, C. D., L. C. Murdoch, D. P. Genereux, D. R. Corbett, K. Stone, P. Pham, and H. Mitasova (2010), Comparison of Darcian flux calculations and seepage meter measurements in a sandy streambed in North Carolina, United States, Water Resour. Res., 46, W09501, doi: 10.1029/2009WR008342.

Kilpatrick, F. A., and E. D. Cobb (1985), Measurement of discharge using tracers, U.S. Geol. Surv.Tech. Water Resour. Invest., TWRI3-A16, 63 pp. [Available at http://pubs.usgs.gov/twri/twri3-a16/.]

Kilpatrick, F. A., R. E. Rathbun, N. Yotsukura, G. W. Parker, and L. L. Delong (1989), Determination of stream reaeration coefficients by use of tracers, U.S. Geol. Surv. Tech. Water Resour. Invest., TWRI3-A18, 52 pp. [Available at http://pubs.usgs.gov/twri/twri3-a18/.]

$\mathrm{Kim}, \mathrm{H}$., and H. Hemond (1998), Natural discharge of volatile organic compounds from contaminated aquifer to surface waters, J. Environ. Eng., 124(8), 744-751, doi:10.1061/(ASCE)0733-9372(1998)124:8(744).

Kimball, B. A., and R. L. Runkel (2009), Spatially detailed quantification of metal loading for decision making: Metal mass loading to American Fork and Mary Ellen Gulch, Utah, Mine Water Environ., 28(4), 274-290, doi:10.1007/s10230-009-0085-5.

Kimball, B. A., D. A. Nimick, L. J. Gerner, and R. L. Runkel (1999), Quantification of metal loading in Fisher Creek by tracer injection and synoptic sampling, Park County, Montana, August 1997, U.S. Geol. Surv.Water Resour. Invest., 99-4119, 40 pp. [Available at http://pubs.er. usgs.gov/publication/wrig94119.]

Kimball, B. A., R. L. Runkel, K. Walton-Day, and K. E. Bencala (2002), Assessment of metal loads in watersheds affected by acid mine drainage by using tracer injection and synoptic sampling: Cement Creek, Colorado, USA, Appl. Geochem., 17(9), 1183-1207, doi:10.1016/S08832927(02)00017-3.

Kirkup, L., and B. Frenkel (2006), An Introduction to Uncertainty in Measurement, Cambridge Univ. Press, N. Y.

Krupa, S. L., T. V. Belanger, H. H. Heck, J. T. Brock, and B. J. Jones (1998), Krupaseep: The next generation seepage meter, J. Coastal Res., SI(26), 210-213.

Laursen, A., and S. Seitzinger (2005), Limitations to measuring riverine denitrification at the whole reach scale: Effects of channel geometry, wind velocity, sampling interval, and temperature inputs of N2-enriched groundwater, Hydrobiologia, 545(1), 225-236, doi:10.1007/ s10750-005-2743-3.

Laursen, A. E., and S. P. Seitzinger (2002), Measurement of denitrification in rivers: An integrated, whole reach approach, Hydrobiologia, 485(1-3), 67-81, doi:10.1023/A:1021398431995.

Lee, D. R. (1977), A device for measuring seepage flux in lakes and estuaries, Limnol. Oceanogr., 22(1), 140-147.

Lindsey, B. D., S. W. Phillips, C. A. Donnelly, G. K. Speiran, L. M. Plummer, J. K. Böhlke, M. J. Focazio, W. C. Burton, and E. Busenberg (2003), Residence times and nitrate transport in ground water discharging to streams in the Chesapeake Bay watershed, U.S. Geol. Surv.Water Resour. Invest., 03-4035, 201 pp. 
McMahon, P. B., and J. K. Böhlke (1996), Denitrification and mixing in a stream-aquifer system: Effects on nitrate loading to surface water, J. Hydrol., 186(1-4), 105-128, doi:10.1016/S0022-1694(96)03037-5.

Merriam, J., W. H. McDowell, and W. S. Curry (1996), A high-temperature catalytic oxidation technique for determining total dissolved nitrogen, Soil Sci. Soc. Am. J., 60, 1050-1055.

Modica, E., H. T. Buxton, and L. N. Plummer (1998), Evaluating the source and residence times of groundwater seepage to streams, New Jersey Coastal Plain, Water Resour. Res., 34(11), 2797-2810, doi:10.1029/98WR02472.

Murdoch, L. C., and S. E. Kelly (2003), Factors affecting the performance of conventional seepage meters, Water Resour. Res., 39(9), 1163, doi:10.1029/2002WR001347.

Obenour, D. R., A. M. Michalak, Y. Zhou, and D. Scavia (2012), Quantifying the impacts of stratification and nutrient loading on hypoxia in the northern Gulf of Mexico, Environ. Sci. Technol., 46(10), 5489-5496, doi:10.1021/es204481a.

Paerl, H., L. Valdes, M. Piehler, and C. Stow (2006), Assessing the effects of nutrient management in an estuary experiencing climatic change: The Neuse River estuary, North Carolina, Environ. Manage., 37(3), 422-436, doi:10.1007/s00267-004-0034-9.

Puckett, L. J., C. Zamora, H. Essaid, J. T. Wilson, H. M. Johnson, M. J. Brayton, and J. R. Vogel (2008), Transport and fate of nitrate at the ground-water/surface-water interface, J. Environ. Qual., 37(3), 1034-1050, doi:10.2134/jeq2006.0550.

Rosenberry, D. O. (2005), Integrating seepage heterogeneity with the use of ganged seepage meters, Limnol. Oceanogr. Methods, 3, 131142, doi:10.4319/lom.2005.3.131.

Rosenberry, D. O. (2008), A seepage meter designed for use in flowing water, J. Hydrol., 359(1-2), 118-130, doi:10.1016/ j.jhydrol.2008.06.029.

Rosenberry, D. O., and M. A. Menheer (2006), A system for calibrating seepage meters used to measure flow between ground water and surface water, U.S. Geol. Surv.Water Resour. Invest. 5053, 22 pp. [Available at http://pubs.usgs.gov/sir/2006/5053/.]

Rosenberry, D. O., and J. Pitlick (2009), Local-scale variability of seepage and hydraulic conductivity in a shallow gravel-bed river, Hydrol. Processes, 23(23), 3306-3318, doi:10.1002/hyp.7433.

Smith, R. L., B. L. Howes, and J. H. Duff (1991), Denitrification in nitrate-contaminated groundwater: Occurrence in steep vertical geochemical gradients, Geochim. Chosmochim. Acta., 55(7), 1815-1825, doi:10.1016/0016-7037(91)90026-2.

Solder, J. E. E. (2014), Quantifying groundwater-surface water exchange: Development and testing of Shelby tubes and seepage blankets as discharge measurement and sample collections devices, MS thesis, 152 pp., Dep. of Geol. and Geophysics, Univ. of Utah, Salt Lake City. [Available at http://content.lib.utah.edu/cdm/singleitem/collection/etd3/id/3170/rec/1.]

Solomon, D. K., T. E. Gilmore, J. E. Solder, B. A. Kimball, and D. P. Genereux (2015), Evaluating an unconfined aquifer by analysis of agedating tracers in stream water, Water Resour. Res., doi:10.1002/2015WR017602, in press.

Stelzer, R. S., D. Drover, S. Eggert, and M. Muldoon (2011a), Nitrate retention in a sand plains stream and the importance of groundwater discharge, Biogeochemistry, 103(1), 91-107, doi:10.1007/s10533-010-9449-y.

Stelzer, R. S., L. A. Bartsch, W. B. Richardson, and E. A. Strauss (2011b), The dark side of the hyporheic zone: Depth profiles of nitrogen and its processing in stream sediments, Freshwater Biol., 56(10), 2021-2033, doi:10.1111/j.1365-2427.2011.02632.x.

Stolp, B. J., D. K. Solomon, A. Suckow, T. Vitvar, D. Rank, P. K. Aggarwal, and L. F. Han (2010), Age dating base flow at springs and gaining streams using helium-3 and tritium: Fischa-Dagnitz system, southern Vienna Basin, Austria, Water Resour. Res., 46, W07503, doi:10.1029/ 2009WR008006.

Taylor, J. R. (1997), An Introduction to Error Analysis, 2nd ed., Univ. Sci. Books, Sausalito, Calif.

Tesoriero, A. J. (2005), Nitrogen transport and transformations in a coastal plain watershed: Influence of geomorphology on flow paths and residence times, Water Resour. Res., 41, W02008, doi:10.1029/2003WR002953.

Tesoriero, A. J., H. Liebscher, and S. E. Cox (2000), Mechanism and rate of denitrification in an agricultural watershed: Electron and mass balance along groundwater flow paths, Water Resour. Res., 36(6), 1545-1559, doi:10.1029/2000WR900035.

Tesoriero, A. J., J. H. Duff, D. A. Saad, N. E. Spahr, and D. M. Wolock (2013), Vulnerability of streams to legacy nitrate sources, Environ. Sci. Technol., 47(8), 3623-3629, doi:10.1021/es305026x.

Visser, A., H. P. Broers, and M. F. P. Bierkens (2007), Dating degassed groundwater with ${ }^{3} \mathrm{H} /{ }^{3} \mathrm{He}$, Water Resour. Res., 43, W10434, doi:10.1029/ 2006 WR005847.

Vogel, J. C., A. S. Talma, and T. H. E. Heaton (1981), Gaseous nitrogen as evidence for denitrification in groundwater, J. Hydrol, 50, 191-200, doi:10.1016/0022-1694(81)90069-X.

Wanninkhof, R., P. J. Mulholland, and J. W. Elwood (1990), Gas exchange rates for a first-order stream determined with deliberate and natural tracers, Water Resour. Res., 26(7), 1621-1630, doi:10.1029/WR026i007p01621.

Winter, T. C., J. W. Harvey, L. O. Franke, and W. M. Alley (1998), Ground Water and Surface Water A Single Resource, U.S. Geol. Surv. Circ., 1139, 79 pp. [Available at http://pubs.usgs.gov/circ/circ1139/.] 